\title{
SAMR and Change
}

Ruben R. Puentedura, Ph.D. 
Prelude: Metaphors 

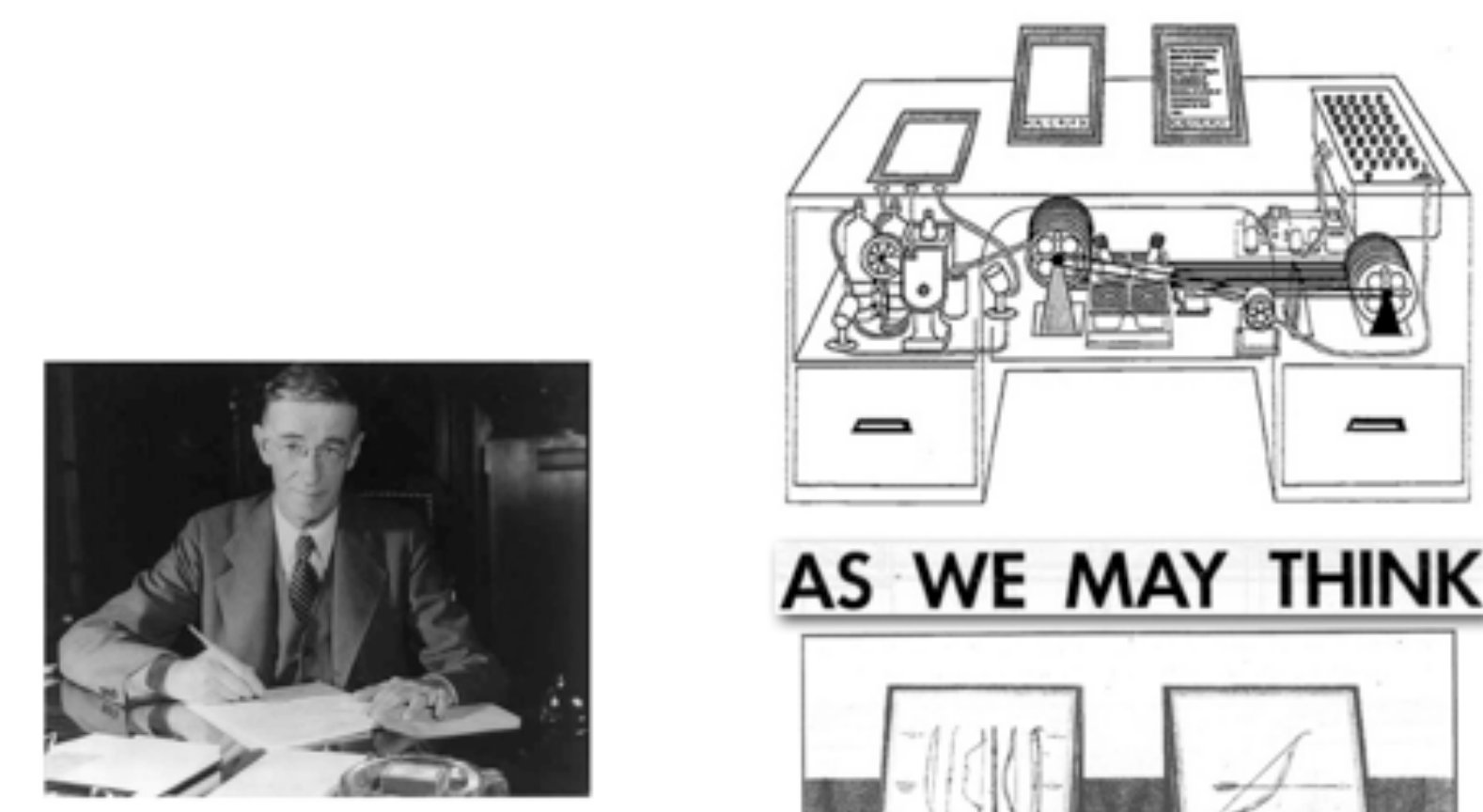

\section{AS WE MAY THINK}
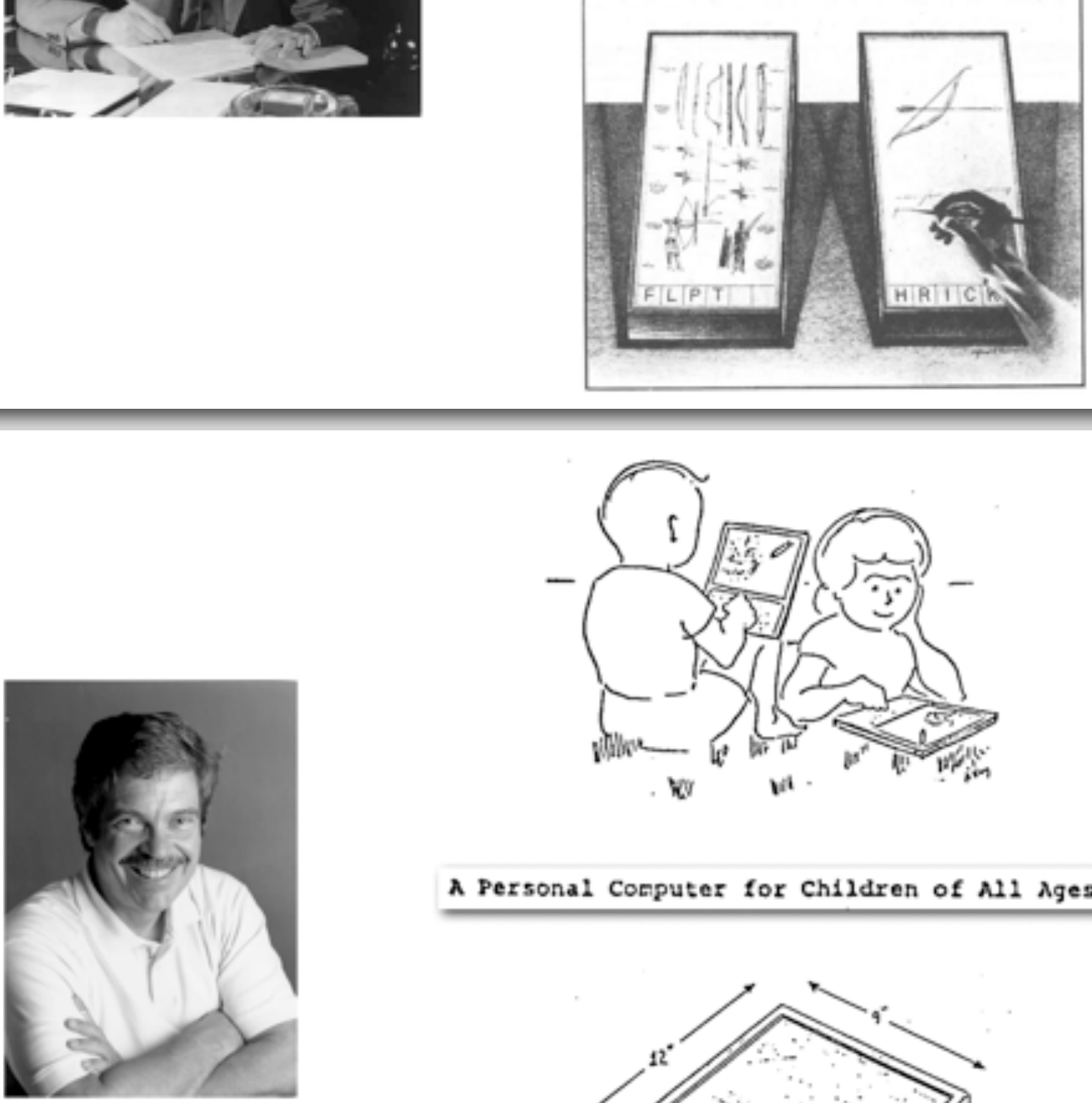

A Personal Computer for Children of All Ages

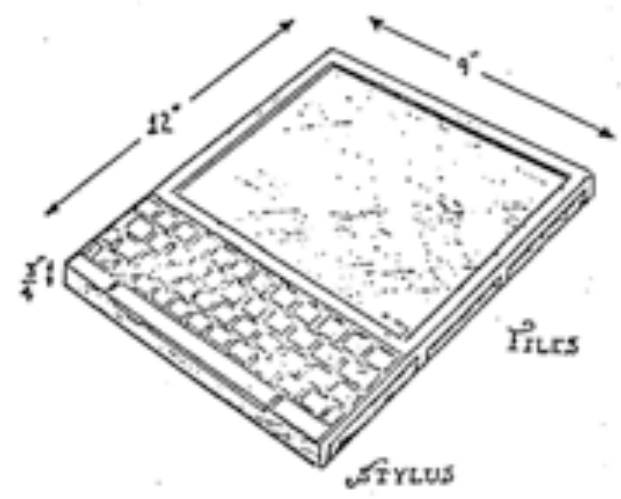

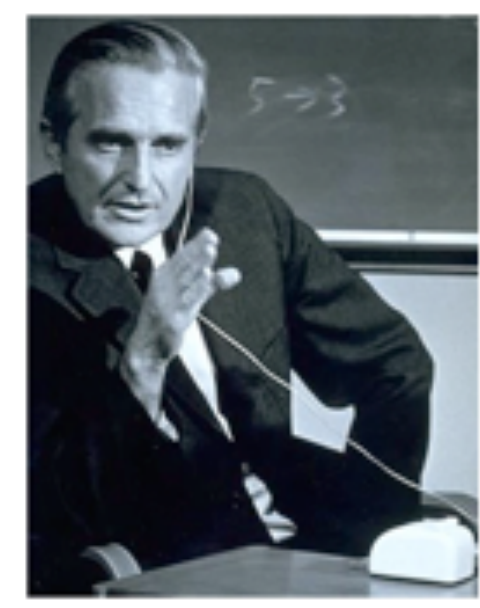

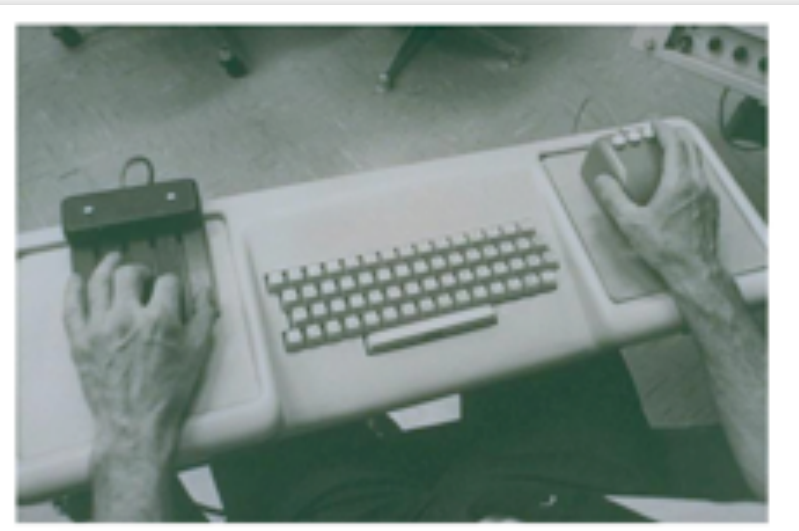

a research center for augmenting human intellect
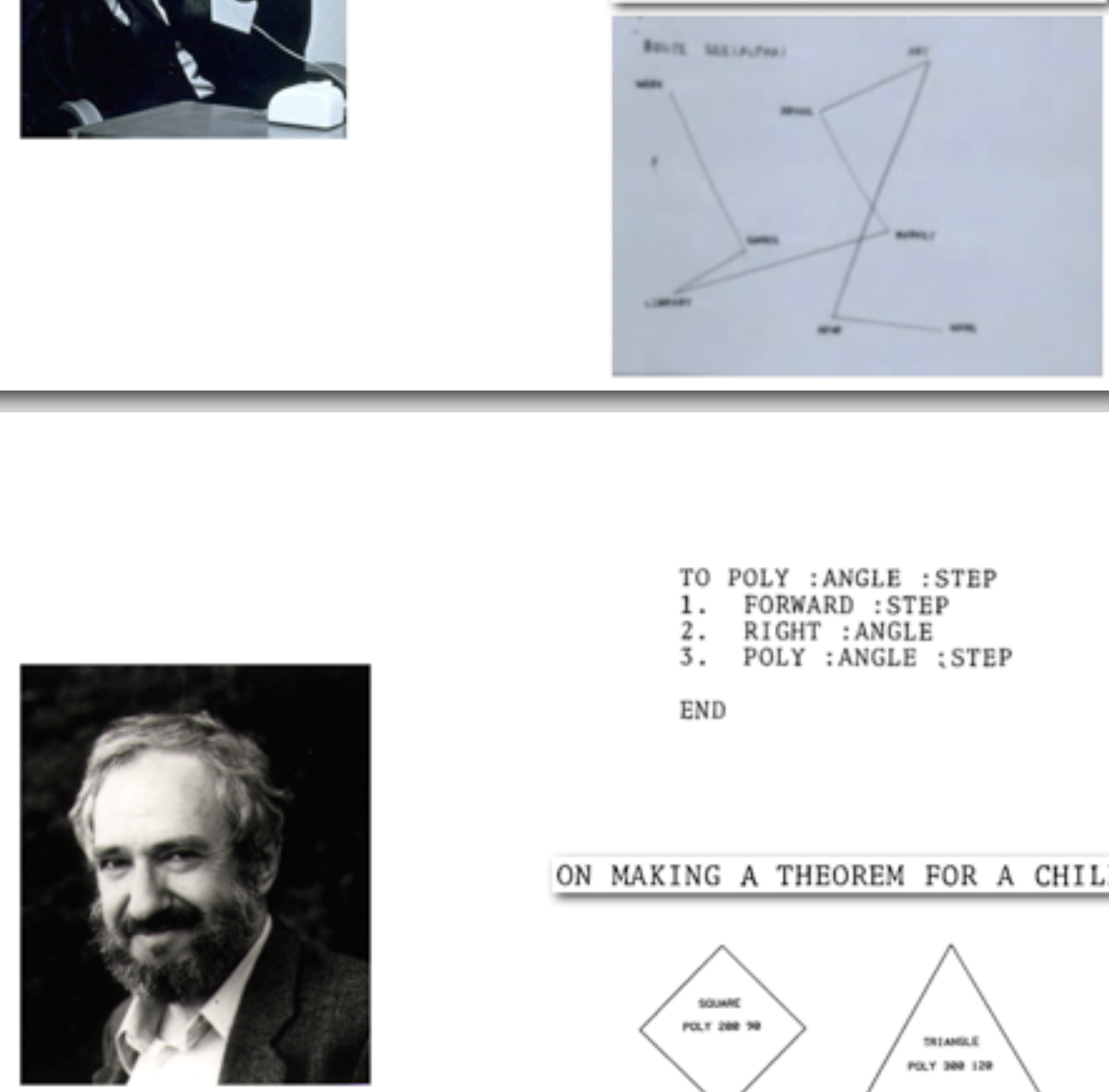

ON MAKING A THEOREM FOR A CHILD

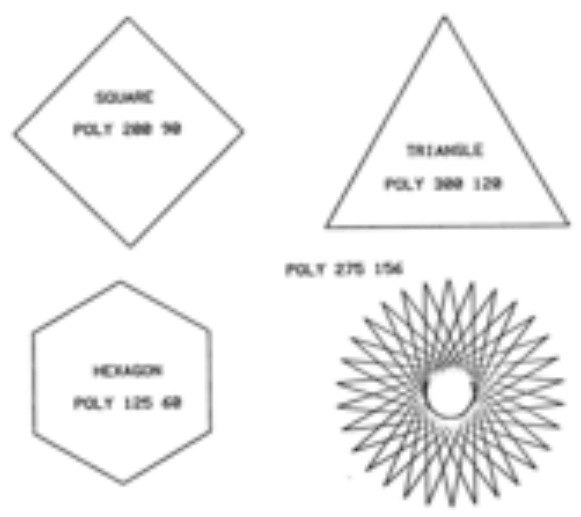




\section{The SAMR Model}




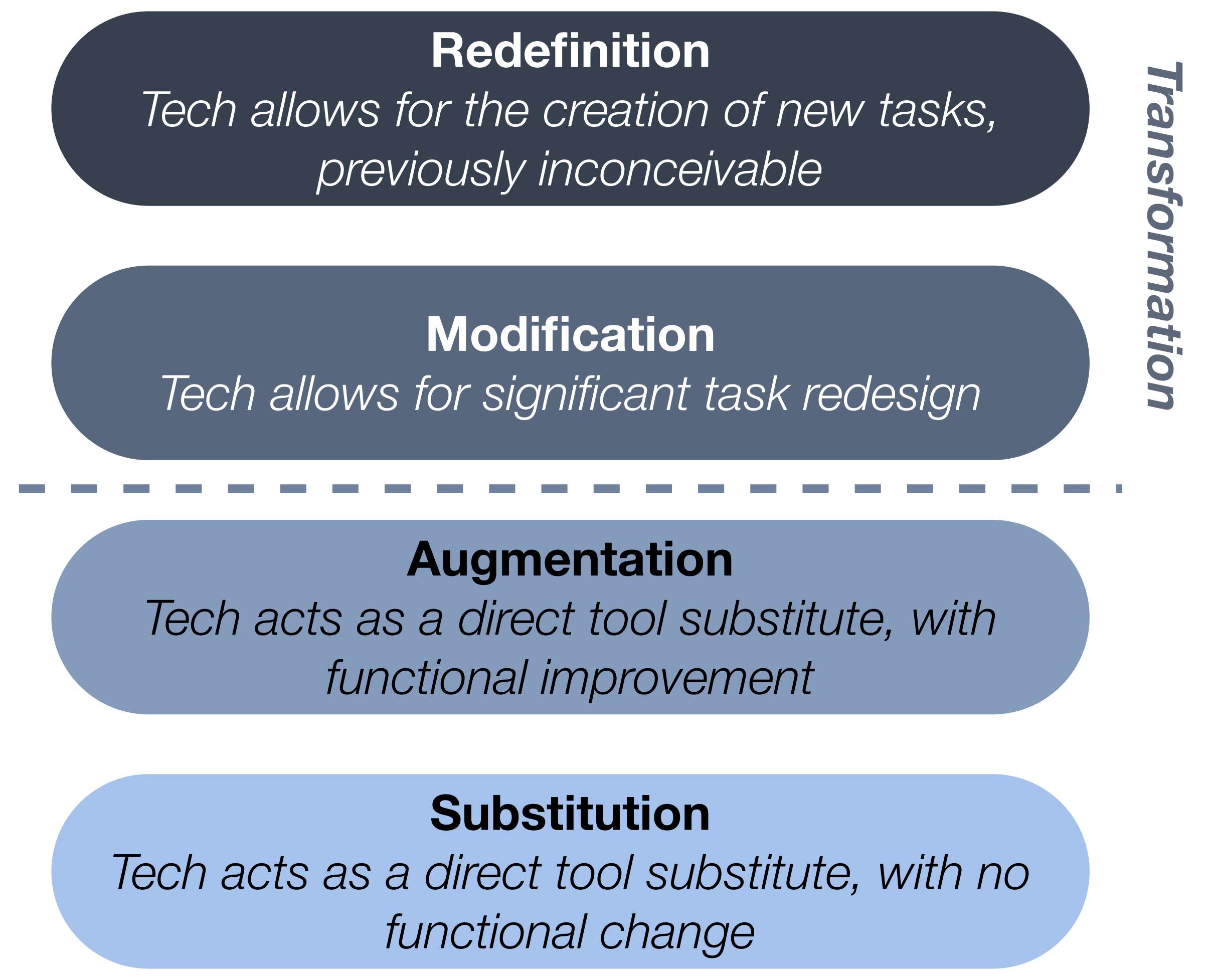


Literacy and Vocabulary 


\section{Marzano: \\ Six Steps to Effective Vocabulary Instruction}

- Step 1: The Teacher Provides a Description, Explanation, or Example of the New Term

- Step 2: Students Restate the Explanation of the New Term in Their Own Words

- Step 3: Students Create a Nonlinguistic Representation of the Term

- Step 4: Students Periodically Do Activities That Help Them Add to Their Knowledge of Vocabulary Terms

- Step 5: Periodically Students Are Asked to Discuss the Terms with One Another

- Step 6: Periodically Students Are Involved in Games That Allow Them to Play with the Terms 


\section{Redefinition}

\section{Tech allows for the creation of new} tasks, previously inconceivable

\section{Modiffcation}

Tech allows for significant task

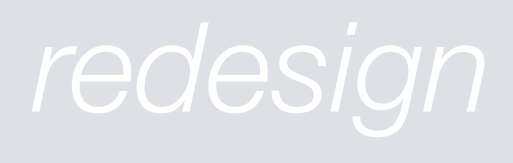

\section{Augmentation}
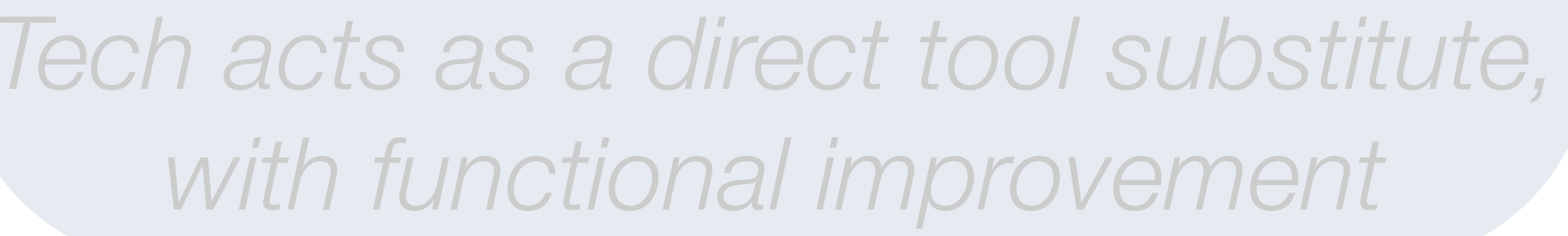

\section{Substitution}

\section{Tech acts as a direct tool substitute, with no functional change}

\section{TALES}

CHAPTER I-THE BOARDING-HOUSE

CHAPTER I.

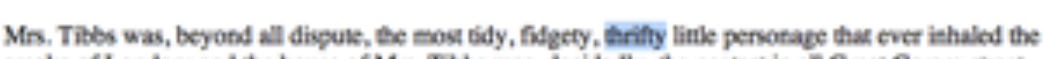

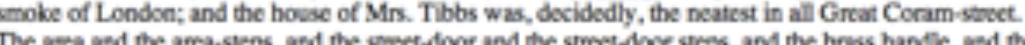
door plaso, and the knocker, and the fan-light, were all as clean and bright, as indefaxigable whito.

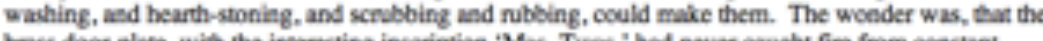

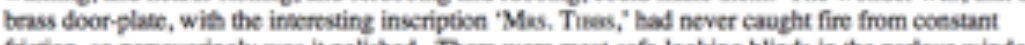

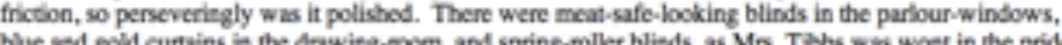

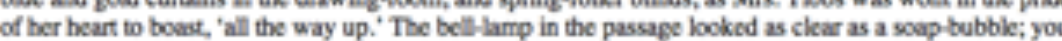
could see younelf in all the ubles, and French-polish yourself on any one of the chair. The banisers were beces waxed; and the very stairwires rado your eyes wink, they were so glithering.

Mr. Tibes was someutas short of stapure, and Mr. Tibbs was by no mears a large man. He had,

\begin{tabular}{|c|c|}
\hline$\theta 0 \theta$ & Dictionary \\
\hline \begin{tabular}{|l|l|l|}
$A$ & $A$ & $A$
\end{tabular} & Q thrifty \\
\hline
\end{tabular}

All Dictionary Thesaurus Apple Wikipedia

thrift•y |' $\theta$ riftē $\mid$

adjective (thriftei-er, thriftri-est)

1 (of a person or their behavior) using money and other resources carefully and not wastefully. See note at ECONOMICAL .

2 chialy archaic dialect (of livestock or plants) strong and healthy. - archaic prosperous.

DERIVATIVES

thrift-i.ly $\mid$-lē| adverb

thriftei-ness noun

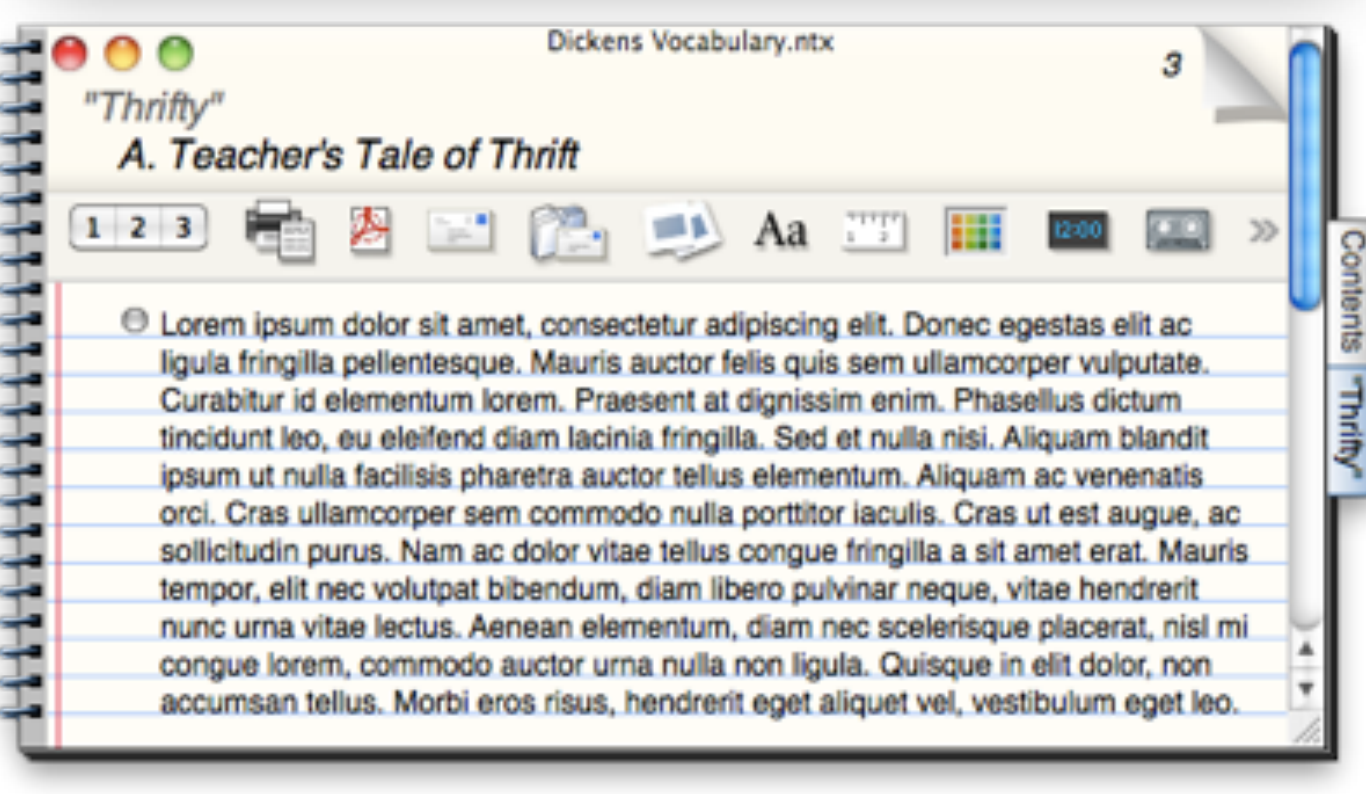




\section{Redefinition}

\section{Tech allows for the creation of new tasks, previously inconceivable}

\section{Modification}

Tech allows for significant task redesign

\section{Augmentation}

Tech acts as a direct tool substitute, with functional improvement

\section{Substitution}

Tech acts as a direct tool substitute,

"Thrifty"
A. Student's Tale of Thrift

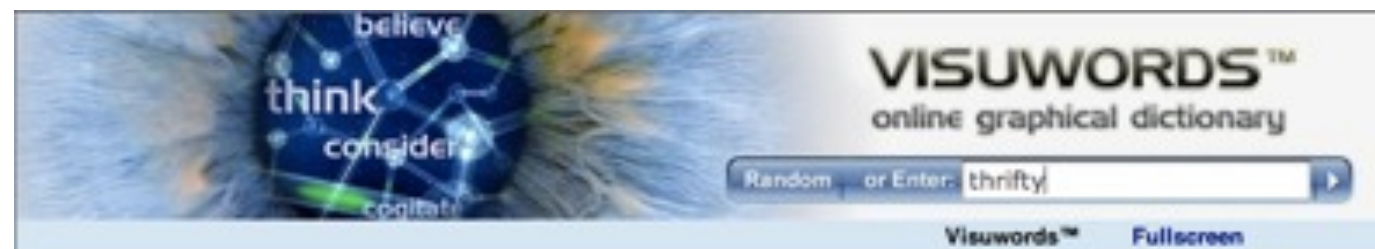

1pigkned

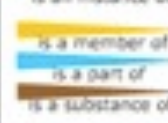

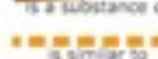

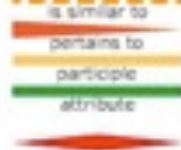

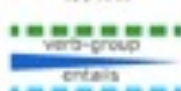

tomes

" " setivetion "

-

Oress

extrom

$\rightarrow$

$\rightarrow$

$135 \bmod 6$
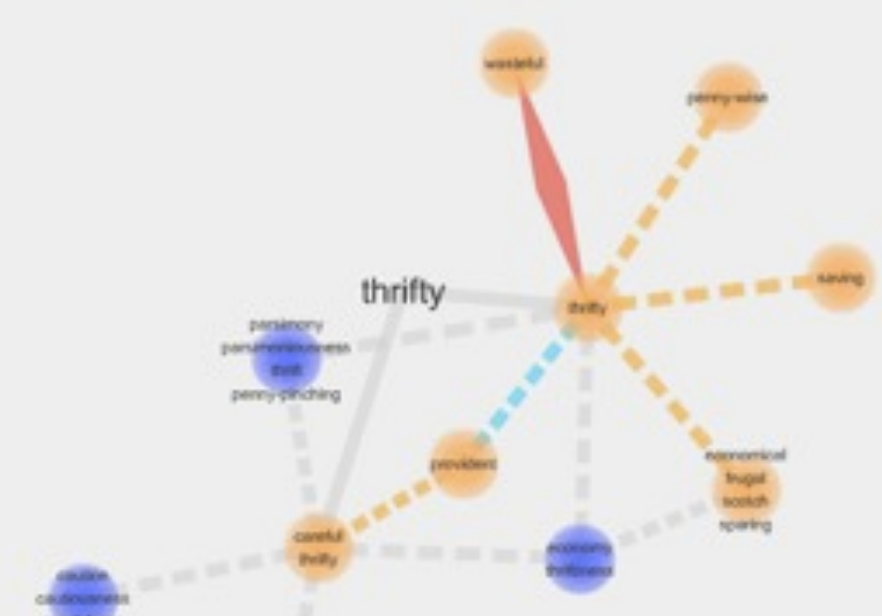

section
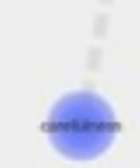

$I$
$I$
$I$ 


\section{Redeffinition}

Tech allows for the creation of new

\section{tasks, previously inconceivable}

\section{Modification}

Tech allows for significant task redesign

\section{Augmentation}

Tech acts as a direct tool substitute, with functional improvement

\section{Substitution
Tech acts as a direct tool substitute, \\ Substitution
Tech acts as a direct tool substitute, with no functional change}

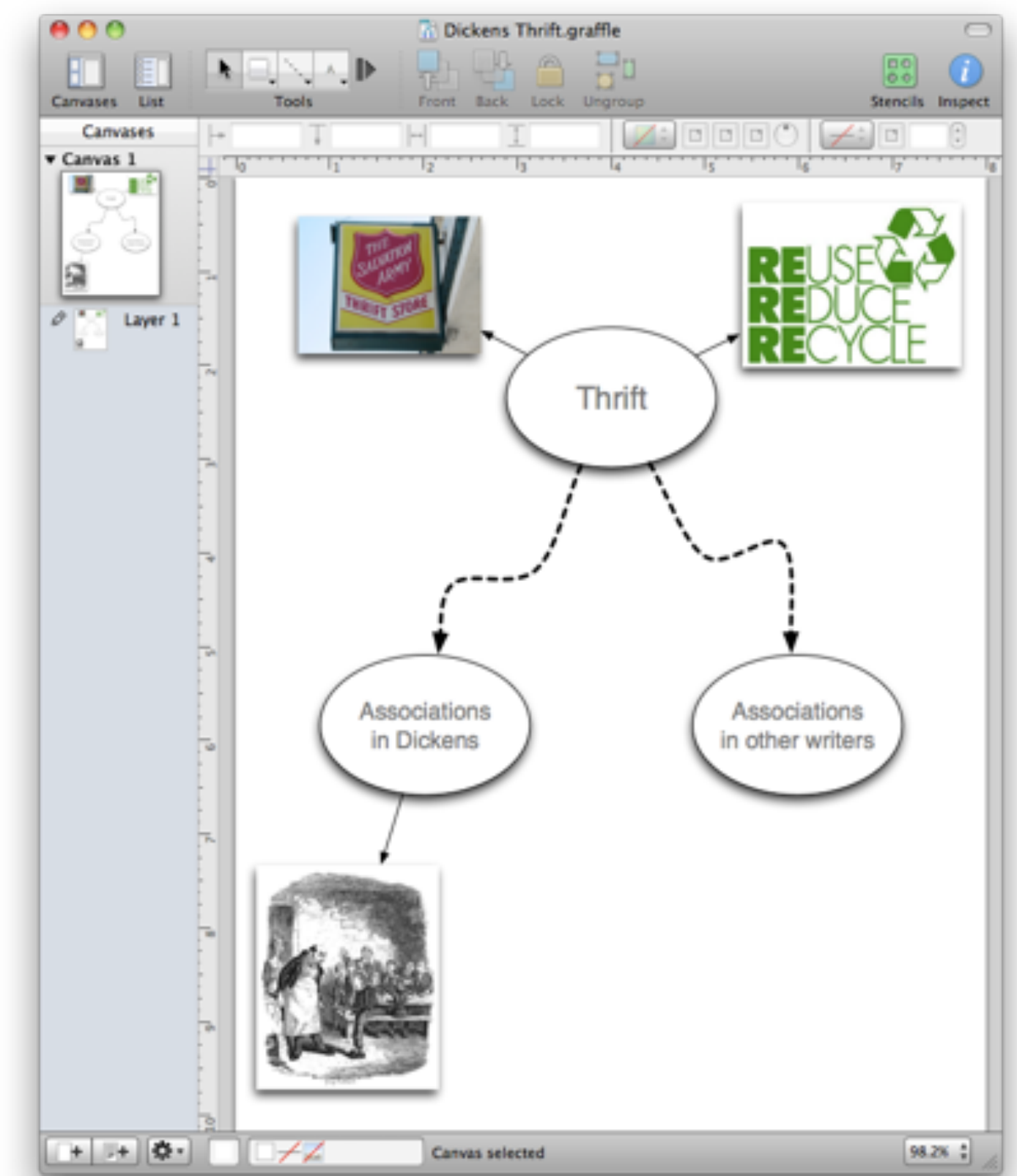




\section{Redefinition}

Tech allows for the creation of new tasks, previously inconceivable

\section{Modification}

Tech allows for significant task redesign

\section{Augmentation}

Tech acts as a direct tool substitute. with functional improvement

\section{Substitution \\ Tech acts as a direct tool substitute, with no functional change}

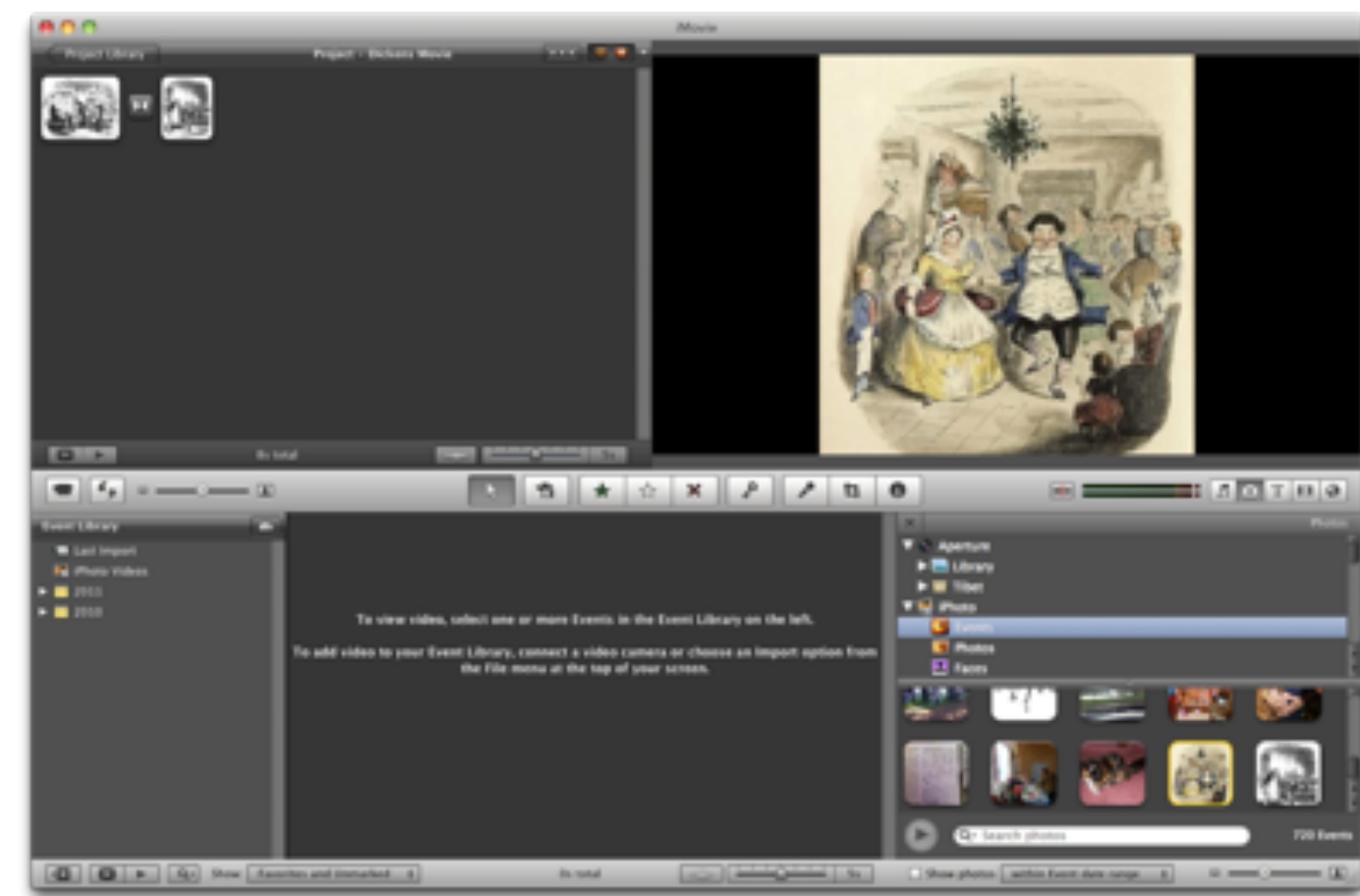




\section{The Student Historian}




\section{Redefinition}

\section{Tech allows for the creation of new tasks, previously inconceivable}

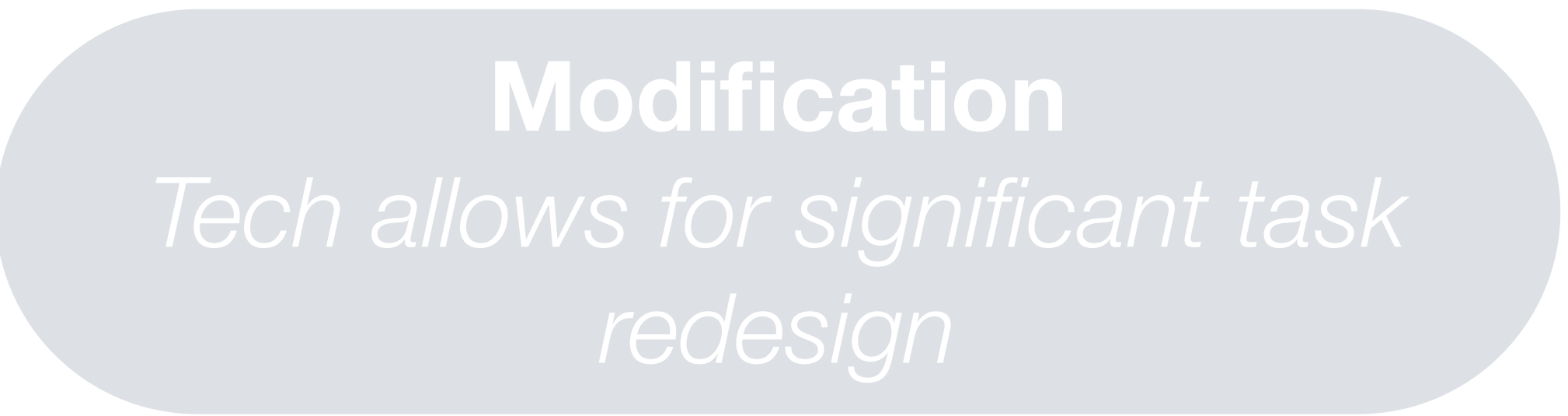

\section{Augmentation}

Tech acts as a direct tool substitute, with functional improvement

\section{Substitution
Tech acts as a direct tool substitute, \\ Substitution
Tech acts as a direct tool substitute, with no functional change}

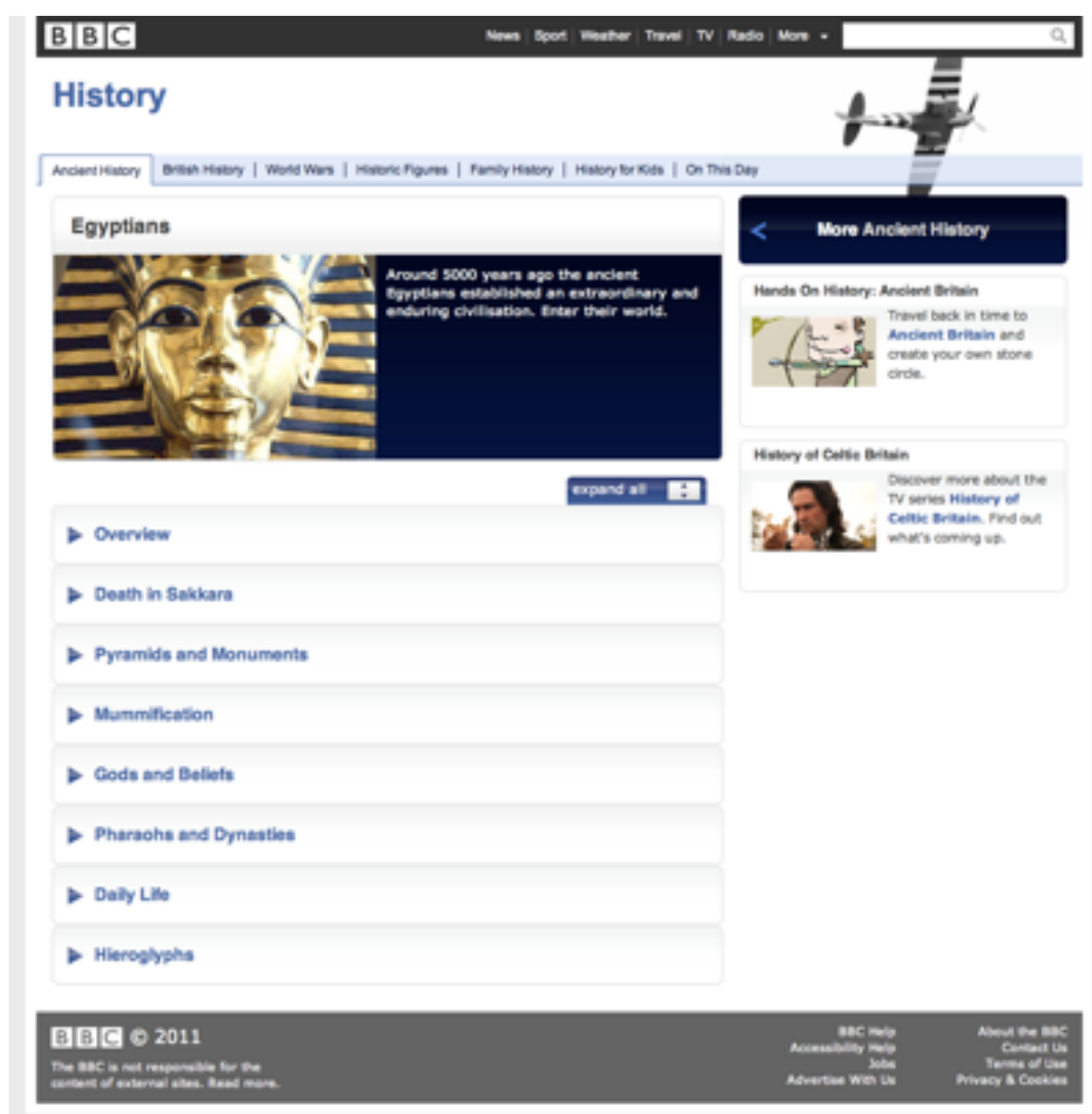




\section{Redeffinition}

\section{Tech allows for the creation of new}

tasks, previously inconceivable

\section{Modification}

Tech allows for significant task redesign

\section{Augmentation}

Tech acts as a direct tool substitute, with functional improvement

\section{Substitution \\ Tech acts as a direct tool substitute, with no functional change}

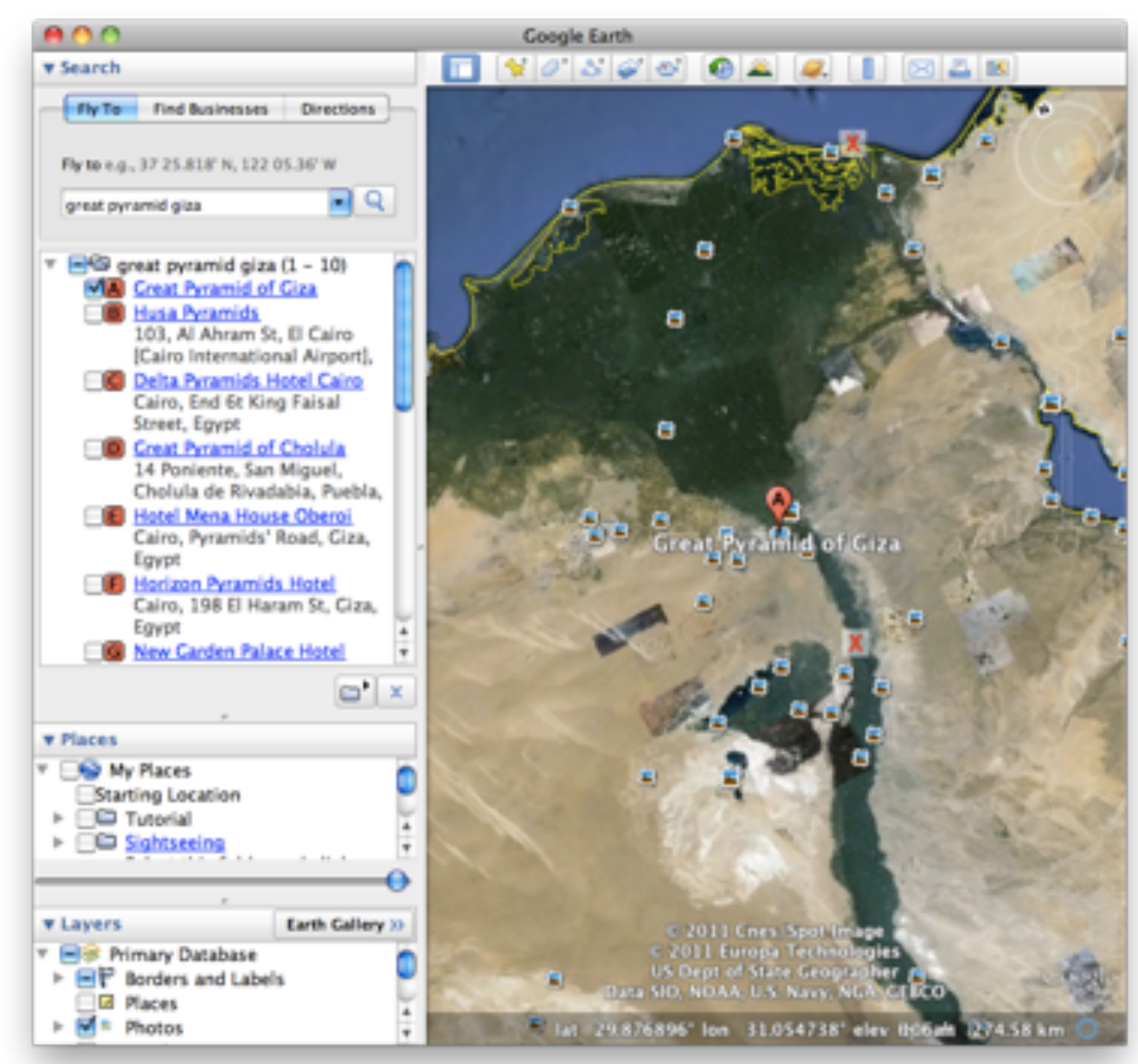




\section{Redeffinition}

Tech allows for the creation of new tasks, previously inconceivable

\section{Modification}

Tech allows for significant task redesign

\section{Augmentation}

Tech acts as a direct tool substitute, with functional improvement

\section{Substitution \\ Tech acts as a direct tool substitute, with no functional change}

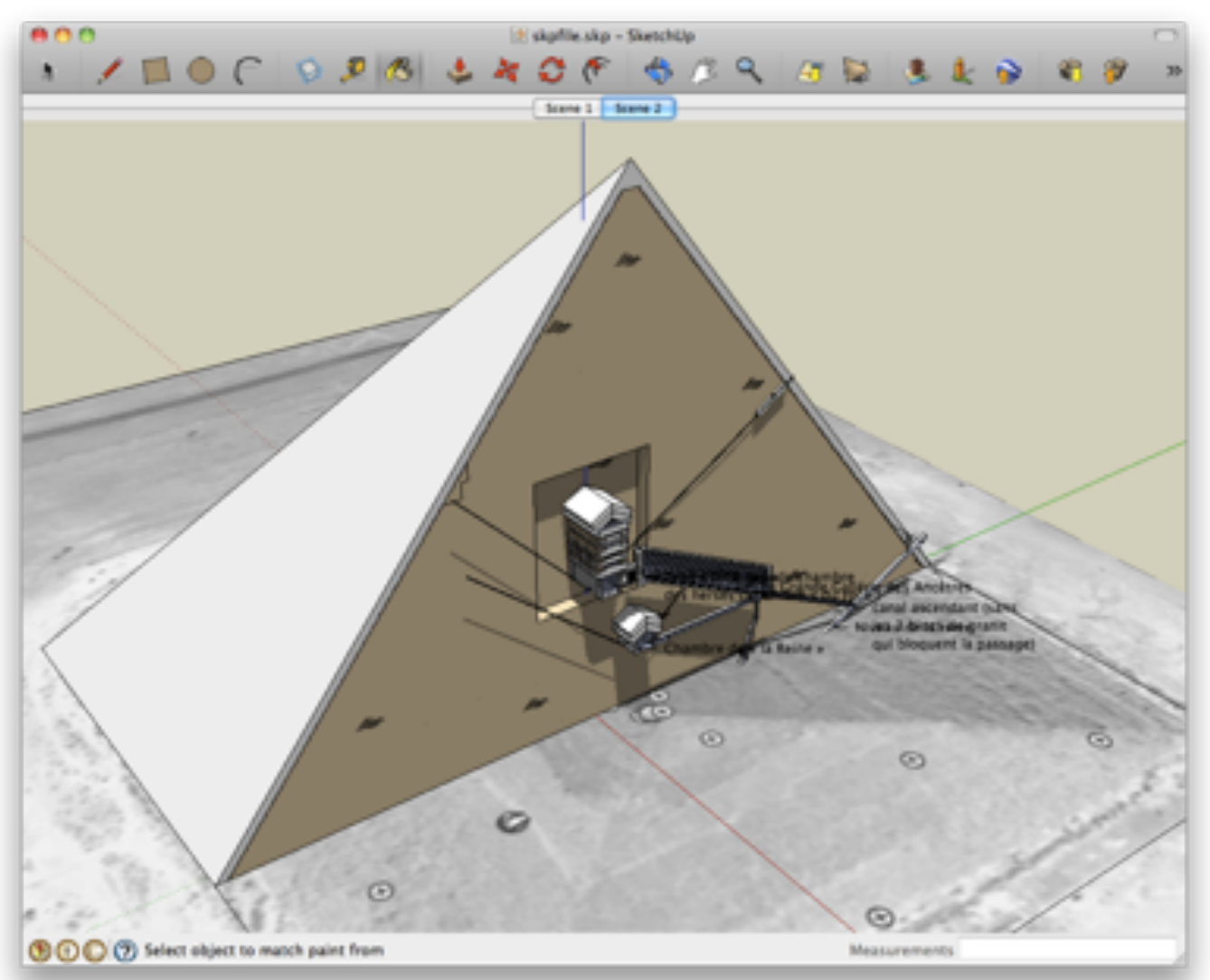




\section{Redefinition}

Tech allows for the creation of new tasks, previously inconceivable

\section{Modification}

Tech allows for significant task redesign

\section{Augmentation}

Tech acts as a direct tool substitute, with functional improvement

\section{Substitution \\ Tech acts as a direct tool substitute, with no functional change}

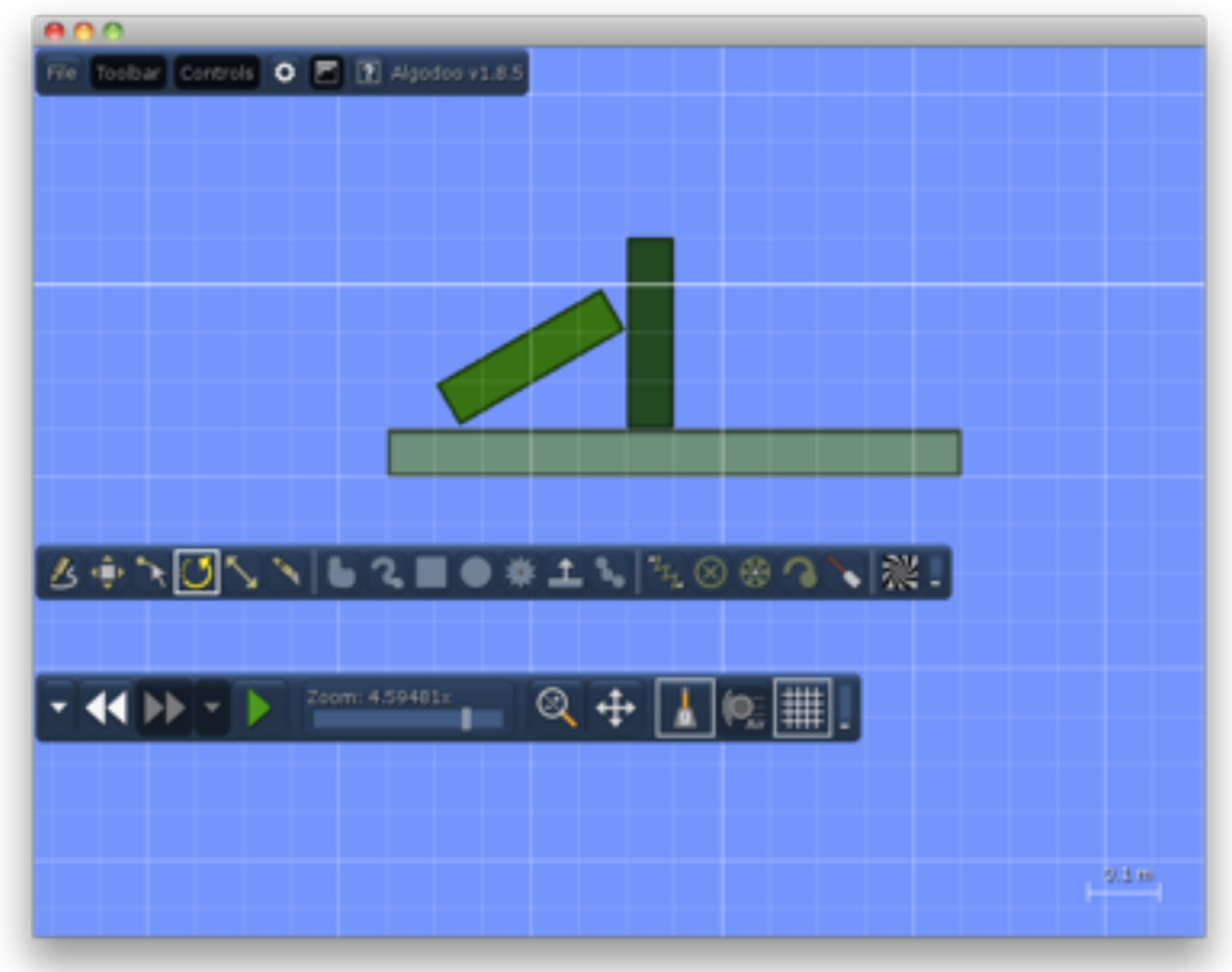


Science as Concrete Abstraction 


\section{Redefinition}

\section{Tech allows for the creation of new tasks, previously inconceivable}
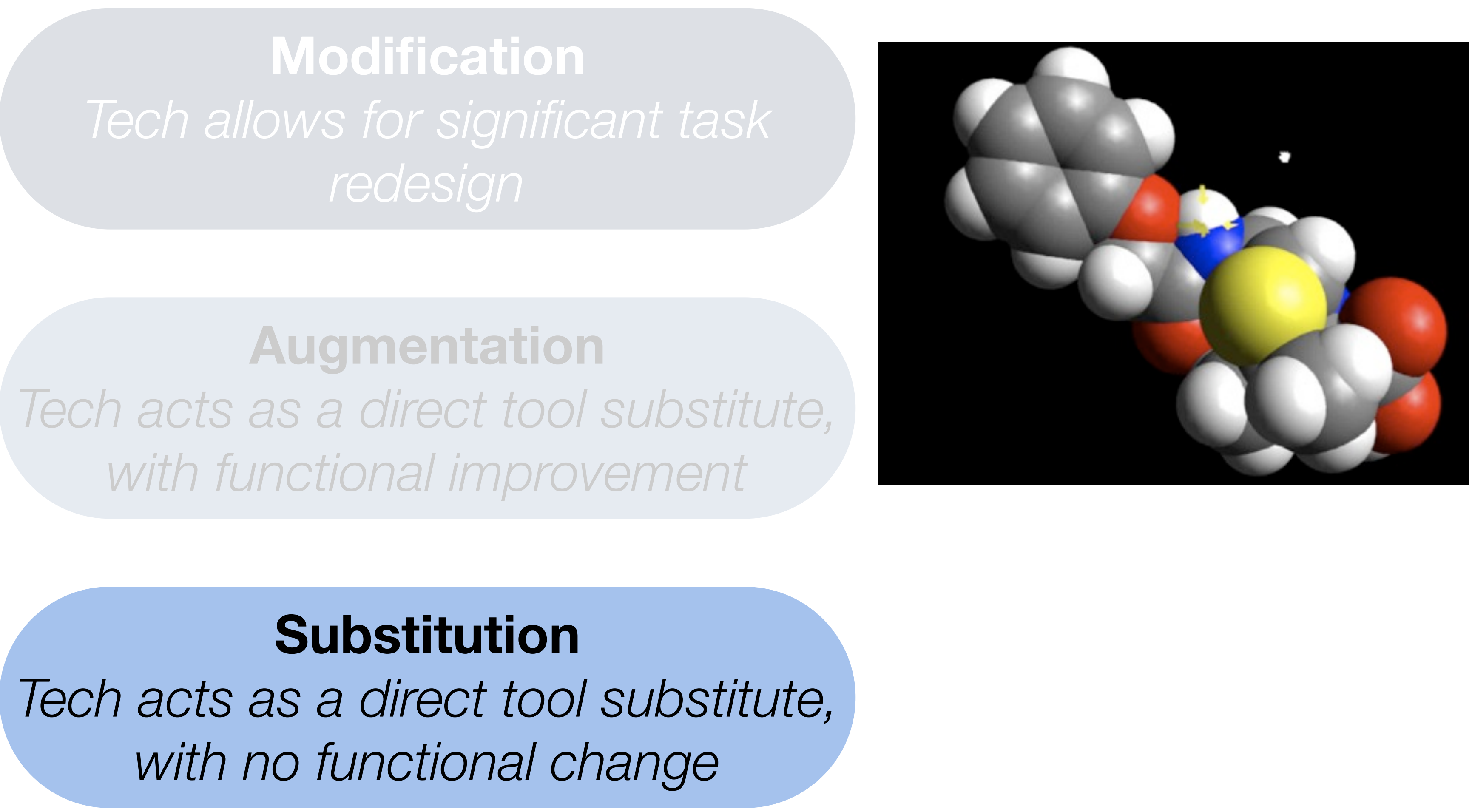

\section{Substitution}

with no functional change 


\section{Redeffinition}

\section{Tech allows for the creation of new tasks, previously inconceivable}

\section{Modification}

Tech allows for significant task redesign

\section{Augmentation}

Tech acts as a direct tool substitute, with functional improvement

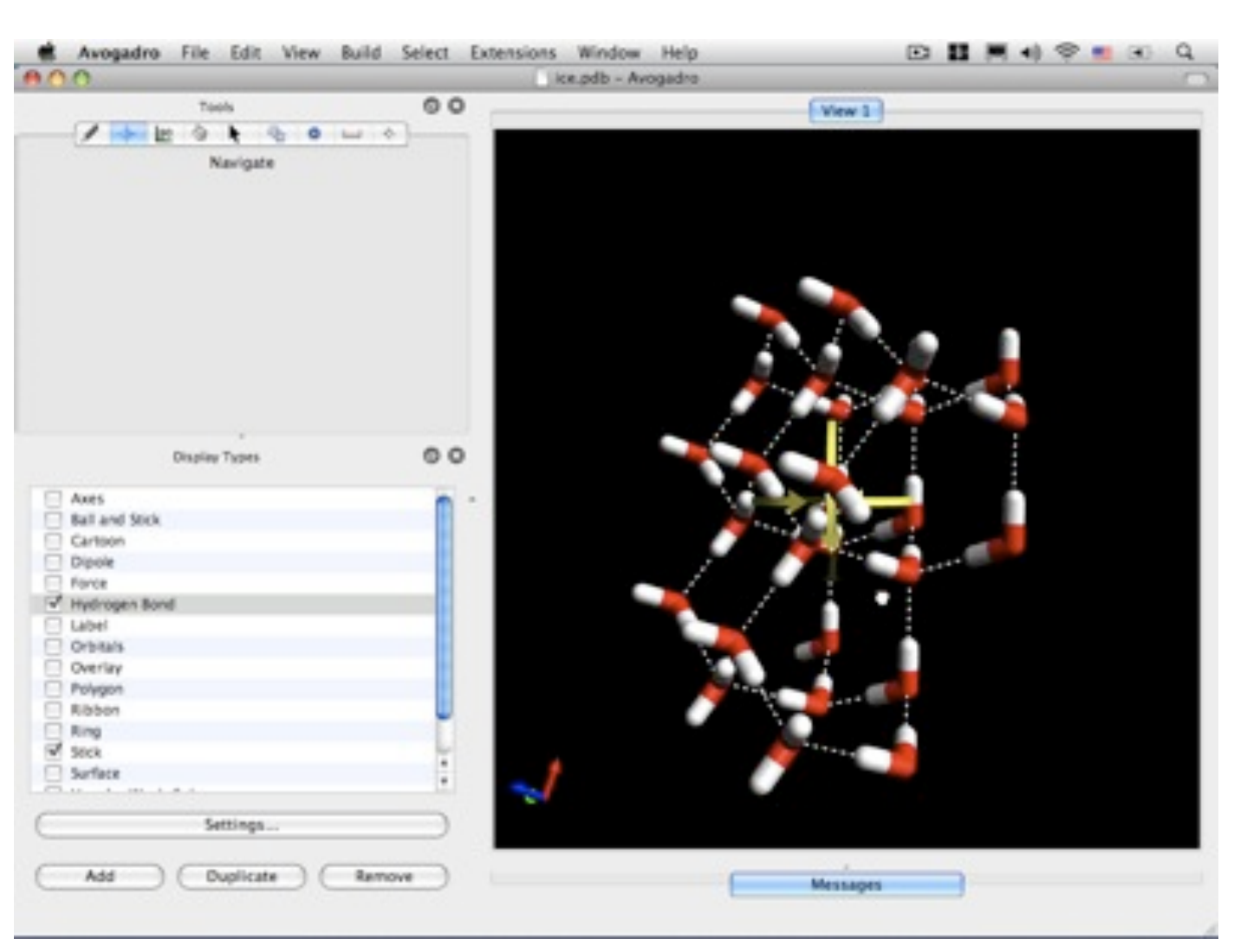

\section{Substitution}

Tech acts as a direct tool substitute, with no functional change 


\section{Redefinition}

Tech allows for the creation of new tasks, previously inconceivable

\section{Modification}

Tech allows for significant task redesign

\section{Augmentation}

Tech acts as a direct tool substitute, with functional improvement

\section{Substitution \\ Tech acts as a direct tool substitute, with no functional change}

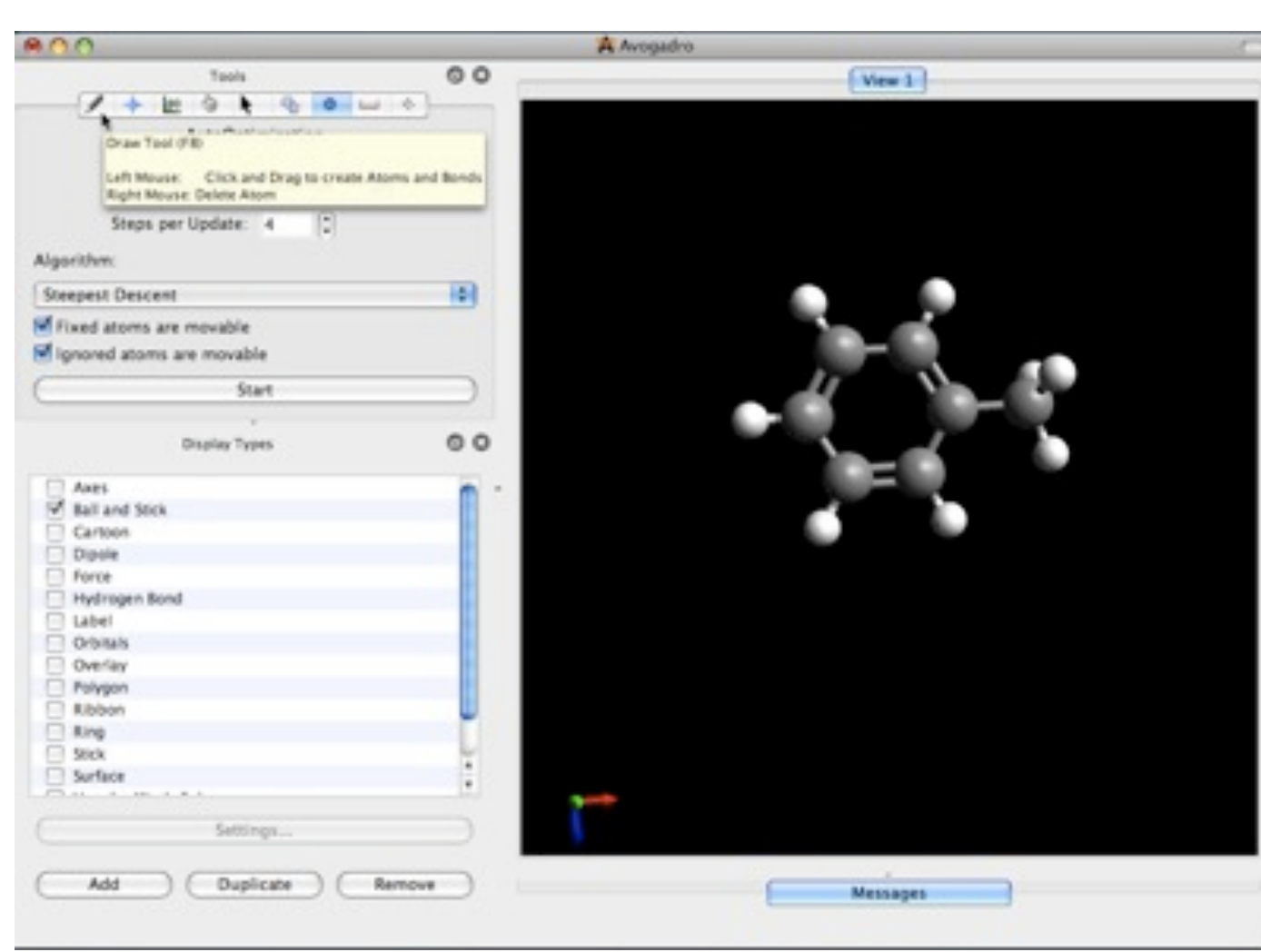




\section{Redefinition}

Tech allows for the creation of new tasks, previously inconceivable

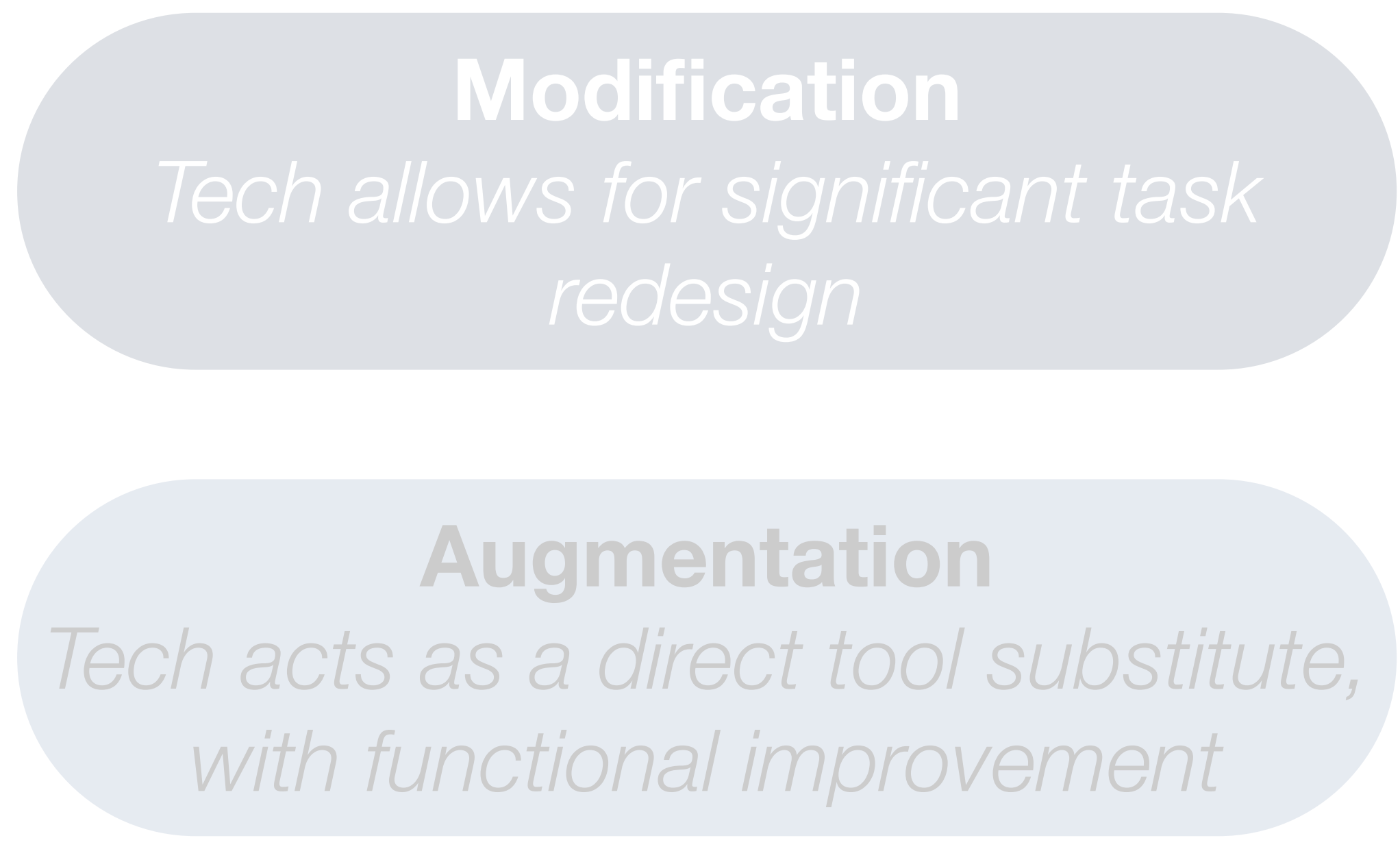

\section{Substitution}

Tech acts as a direct tool substitute, with no functional change

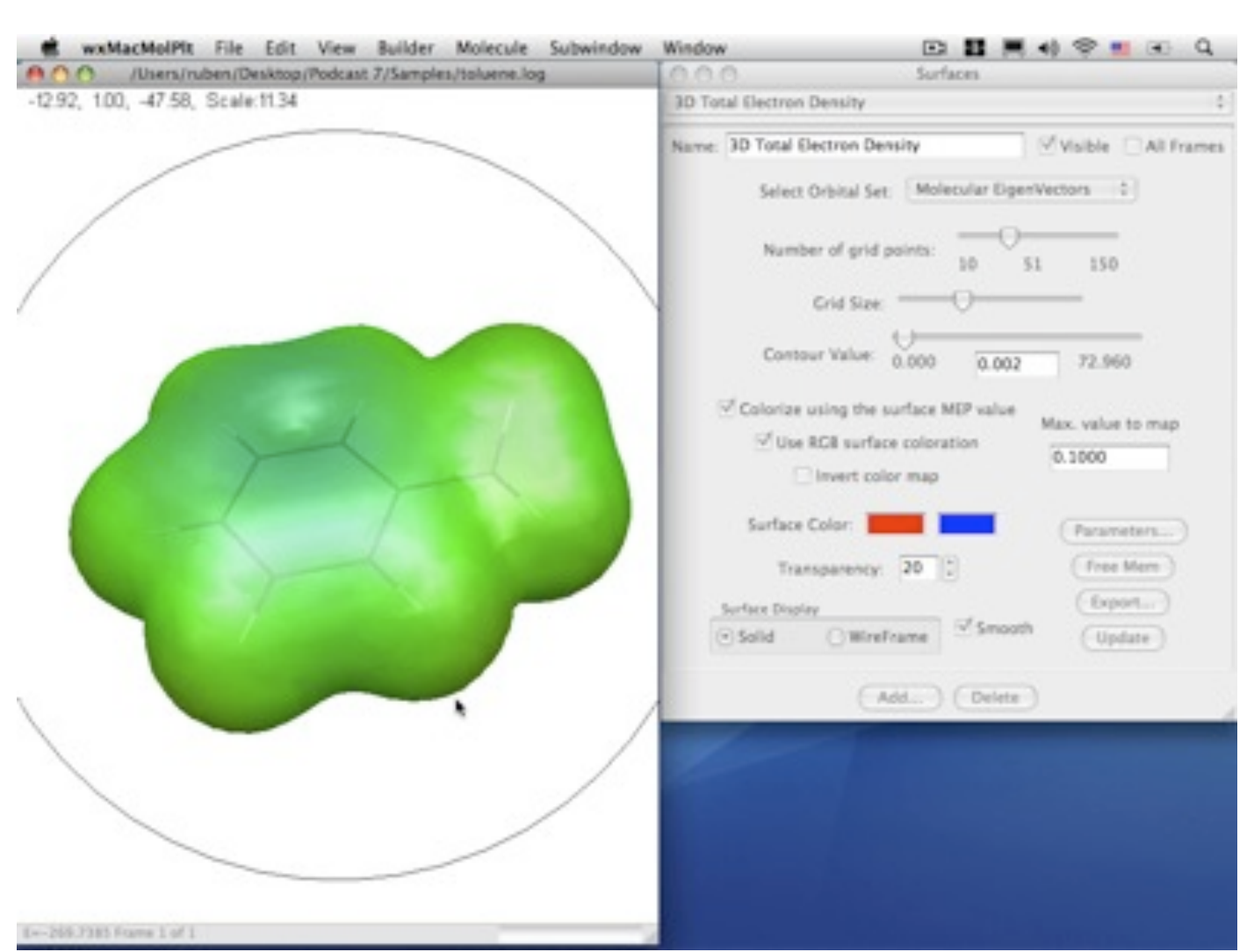


Opening Up the Math Candy Store 


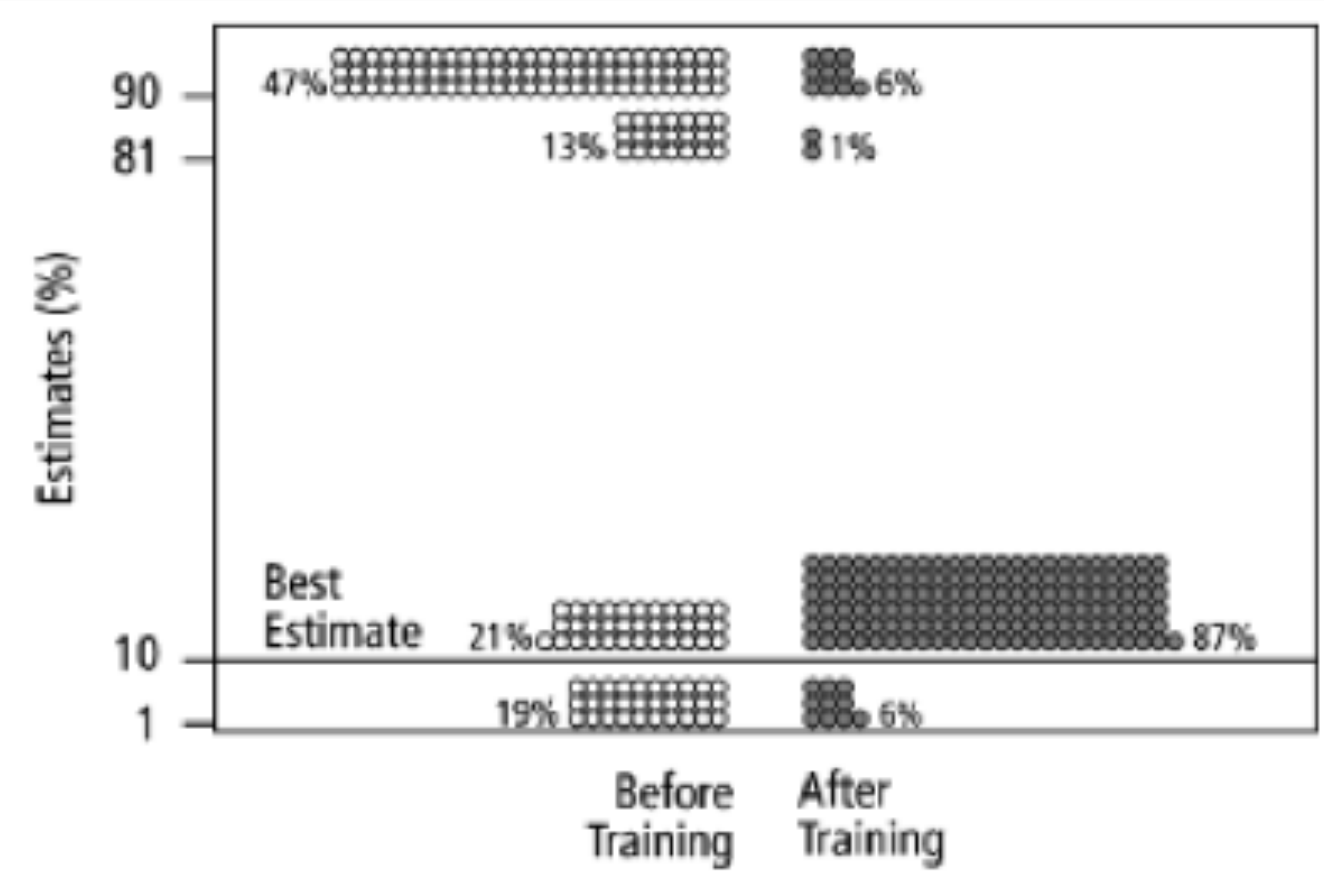

Fig. 2. Estimates by 160 gynecologists of the probability that a woman has breast cancer given a positive mammogram, before and after receiving training in how to translate conditional probabilities into natural frequencies.

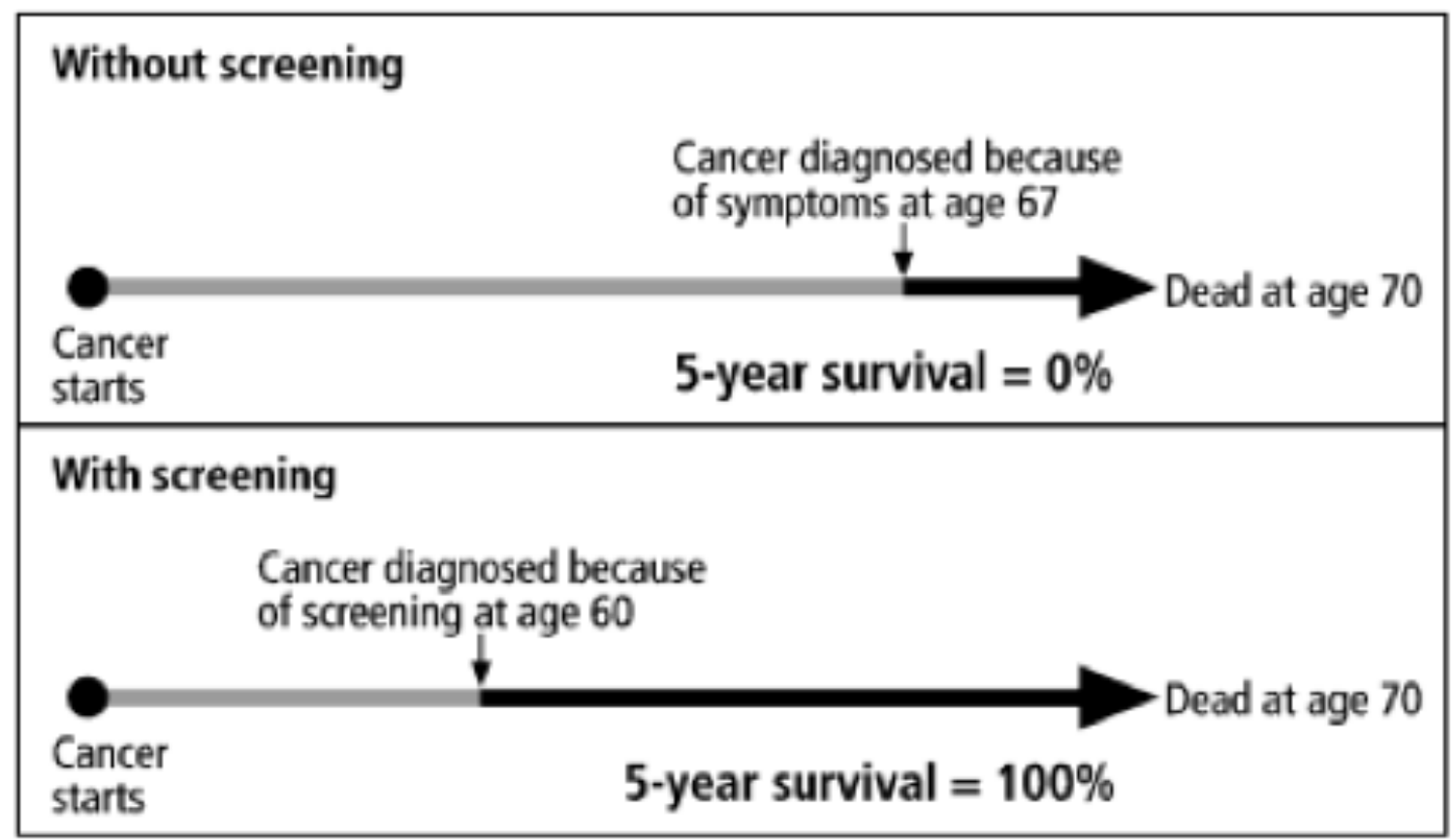

Fig. 4. Lead-time bias. Even if the time of death in not changed by screening - and thus no life is saved or prolonged-advancing the time of diagnosis in this way can result in increased 5-year survival rates, causing such statistics to be misleading. 


\section{Redefinition}

\section{Tech allows for the creation of new tasks, previously inconceivable}

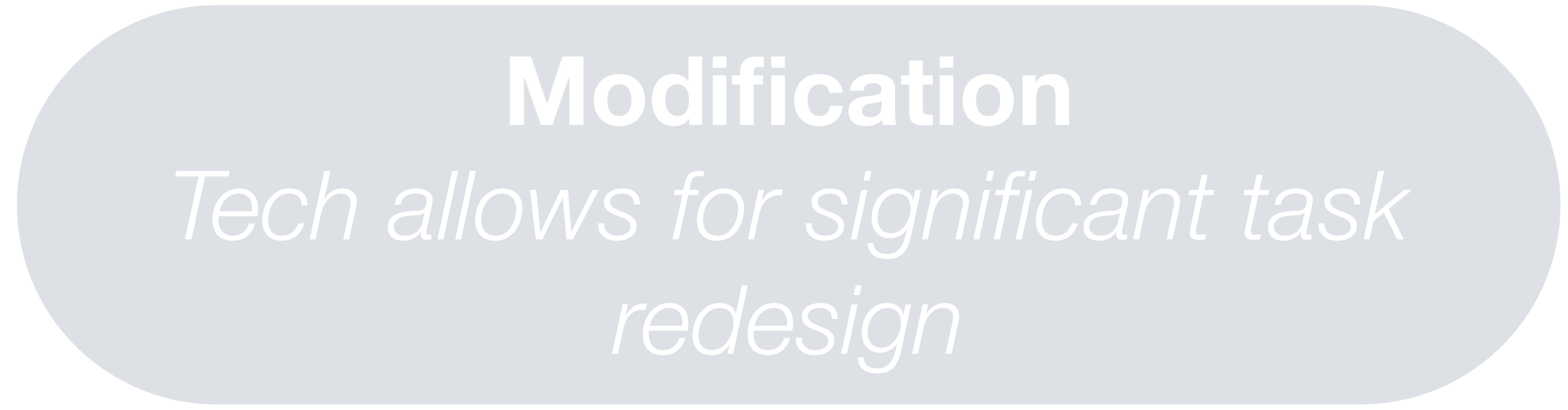

\section{Augmentation}

Tech acts as a direct tool substitute, with functional improvement

\section{Substitution}

Tech acts as a direct tool substitute, with no functional change

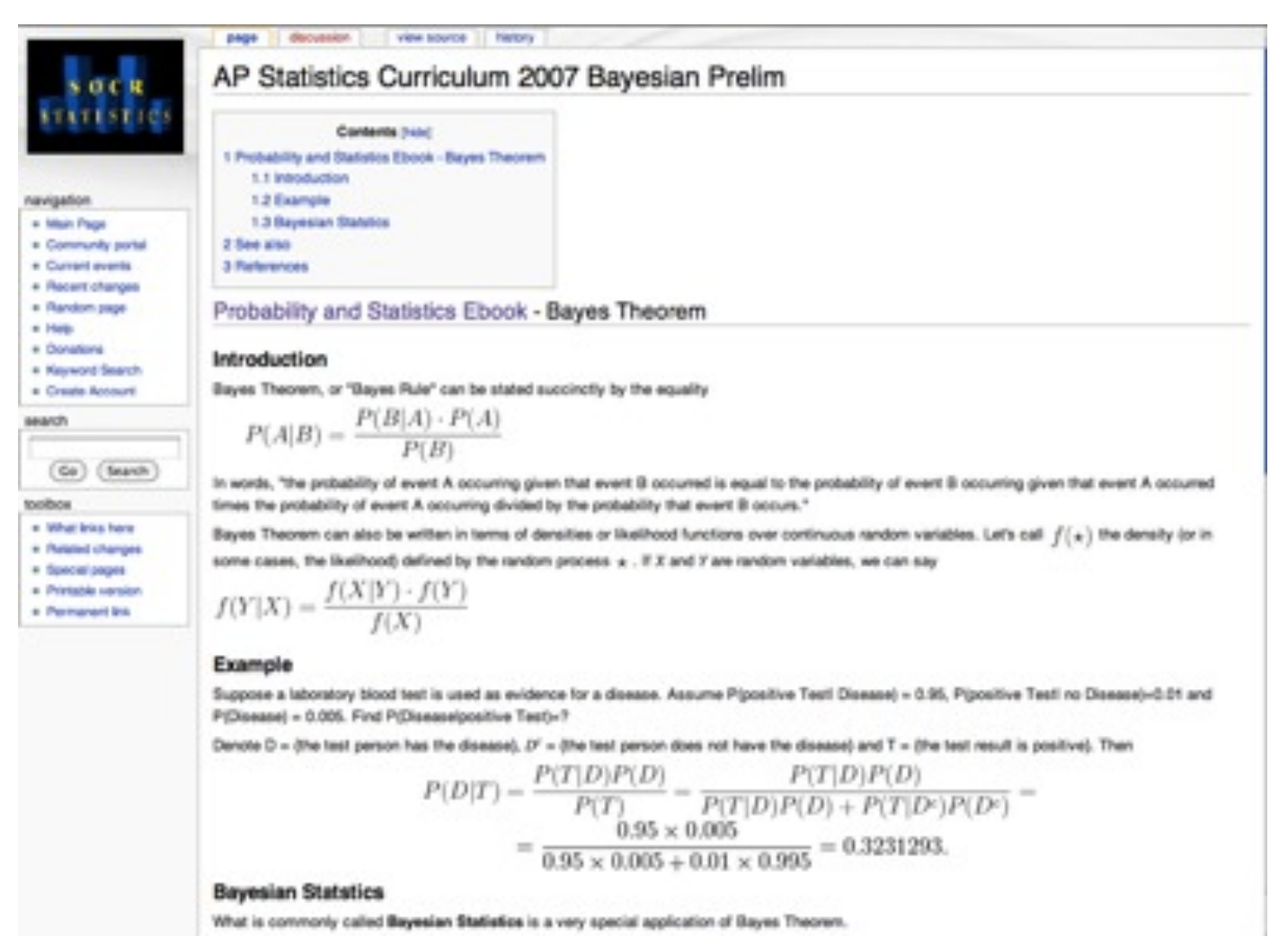




\section{Redefinition}

\section{Tech allows for the creation of new tasks, previously inconceivable}

\section{Modification}

Tech allows for significant task redesign

\section{Augmentation}

Tech acts as a direct tool substitute, with functional improvement

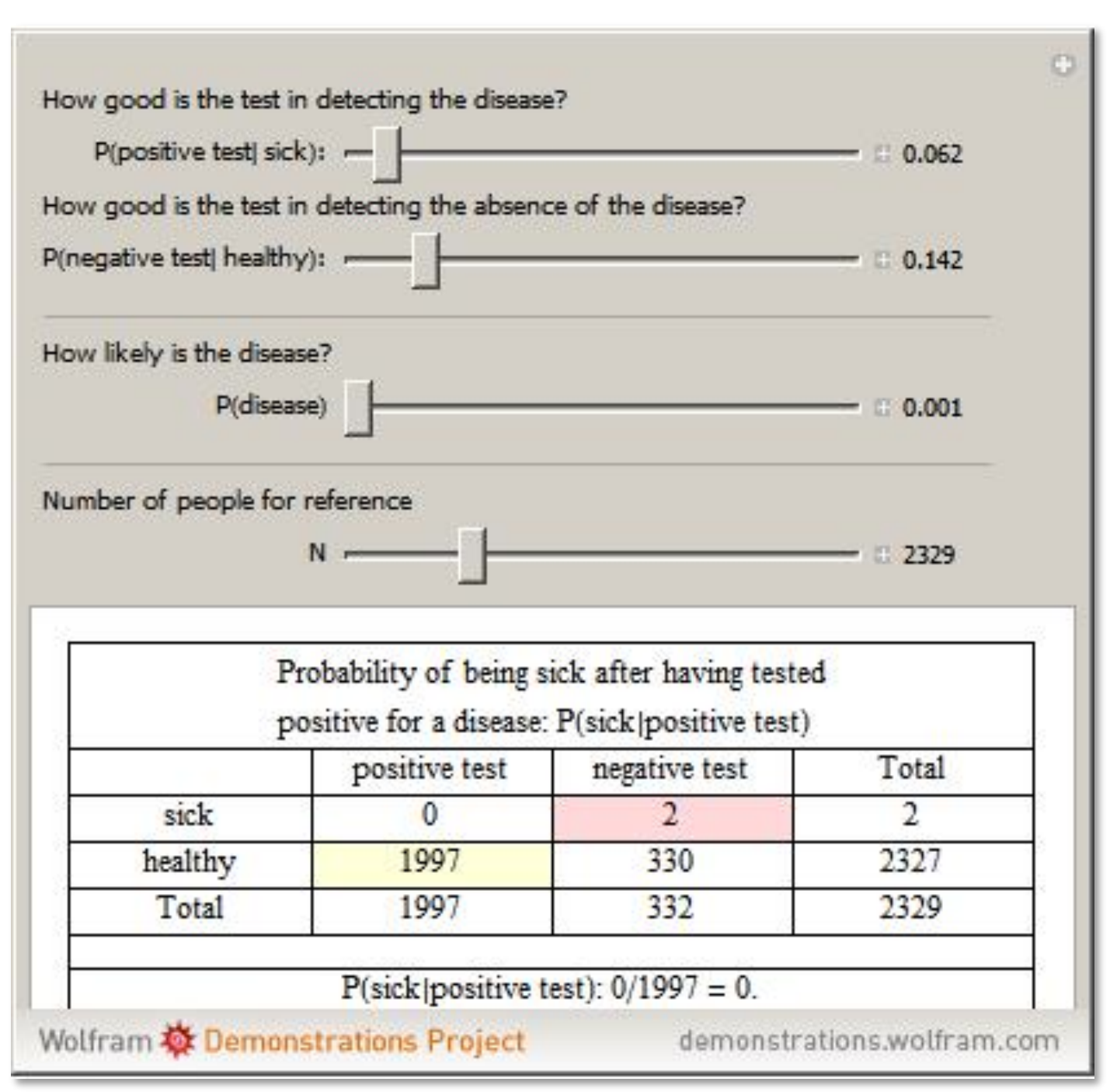

\section{Substitution}

Tech acts as a direct tool substitute, with no functional change 


\section{Redefinition}

\section{Tech allows for the creation of new}

tasks, previously inconceivable

\section{Modification}

Tech allows for significant task redesign

\section{Augmentation}

Tech acts as a direct tool substitute with functional improvement

\section{Substitution \\ Tech acts as a direct tool substitute, with no functional change}

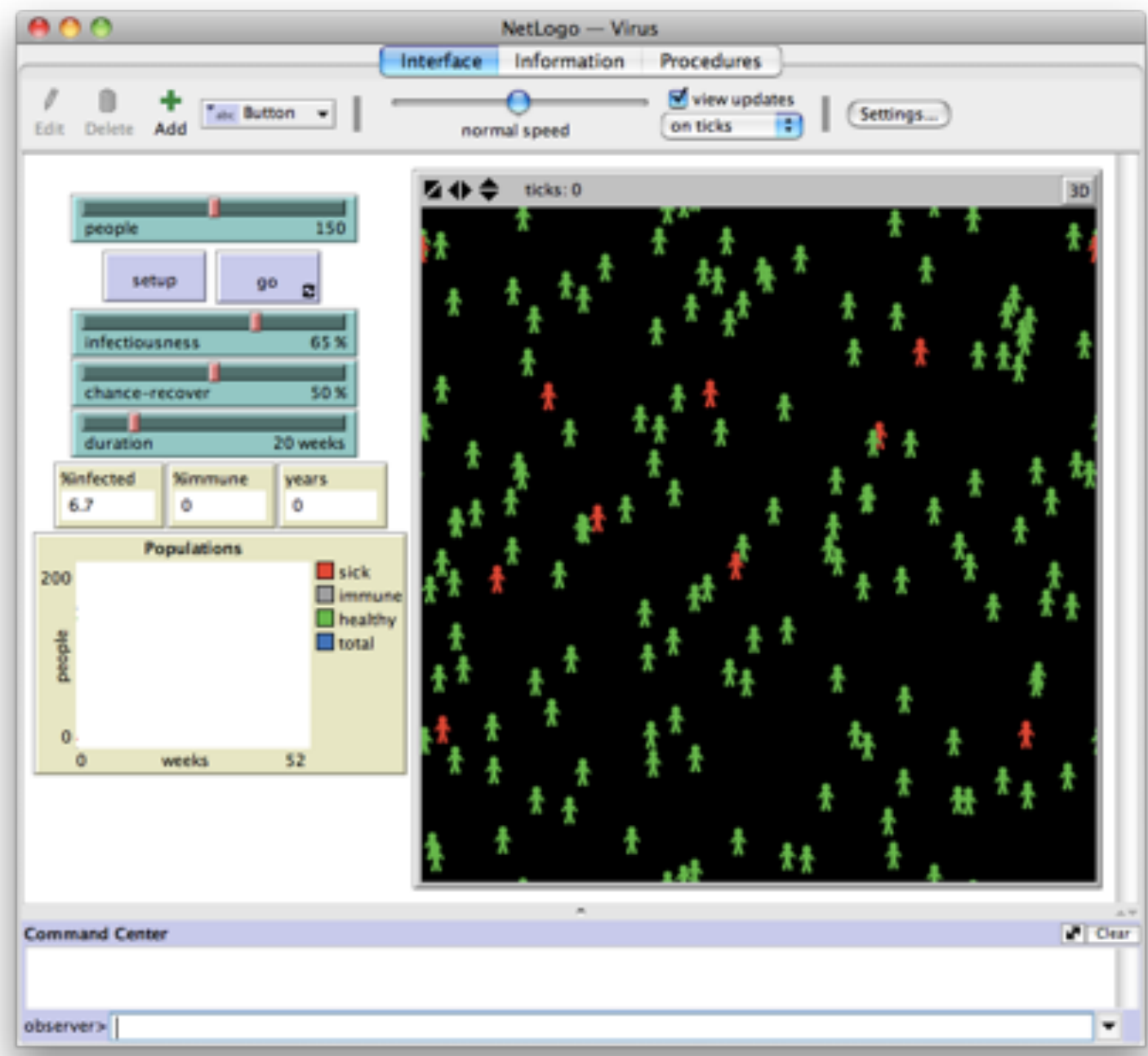




\section{Redefinition}

Tech allows for the creation of new tasks, previously inconceivable

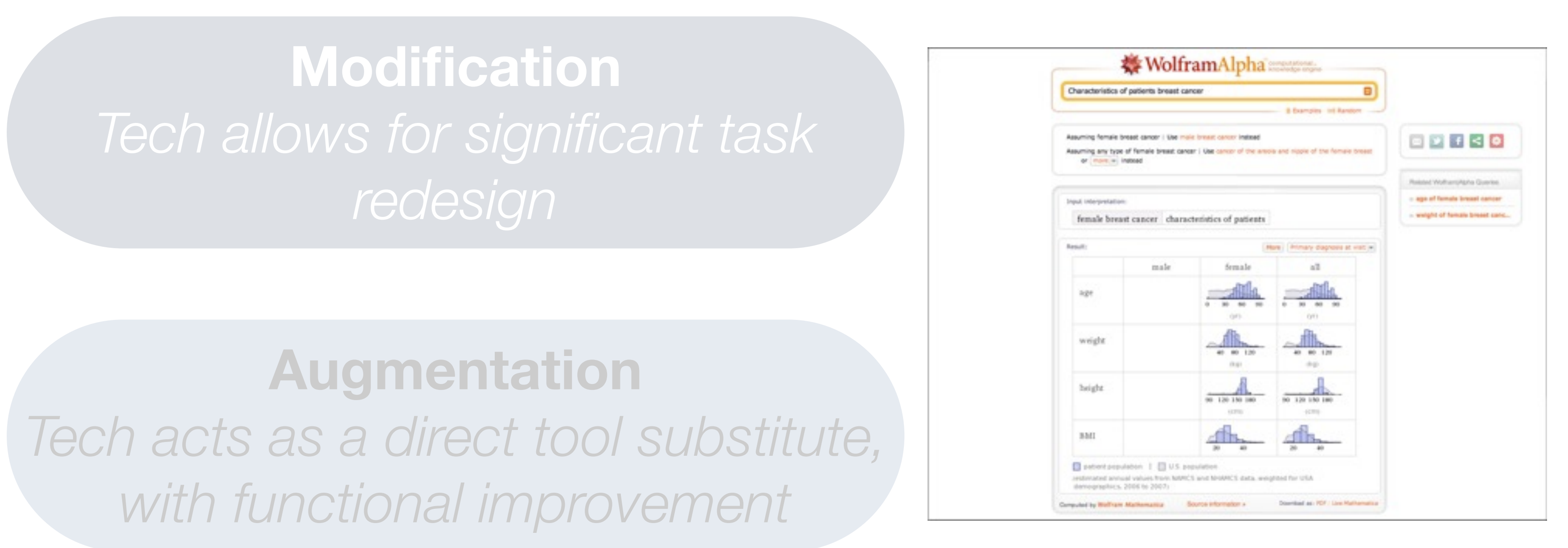

\section{Substitution}

Tech acts as a direct tool substitute, with no functional change 


\section{The Personal Learning Network}




\section{Redefinition}

\section{Tech allows for the creation of new tasks, previously inconceivable}

\section{Modification}

Tech allows for significant task redesign

\section{Augmentation}

Tech acts as a direct tool substitute. with functional improvement

\section{Substitution \\ Tech acts as a direct tool substitute, with no functional change}

\section{HORIZON REPORT}

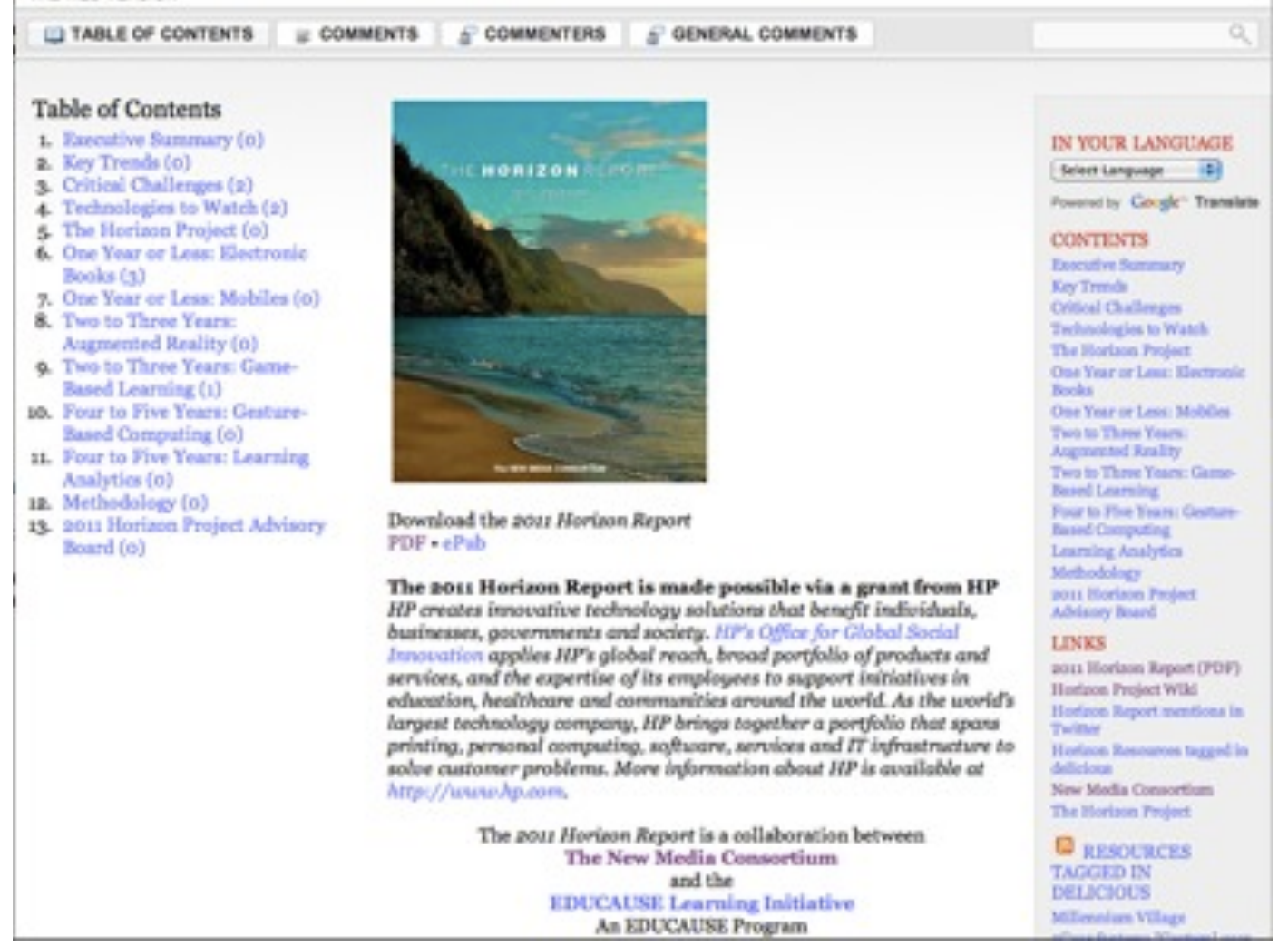




\section{Redefinition}

\section{Tech allows for the creation of new tasks, previously inconceivable}

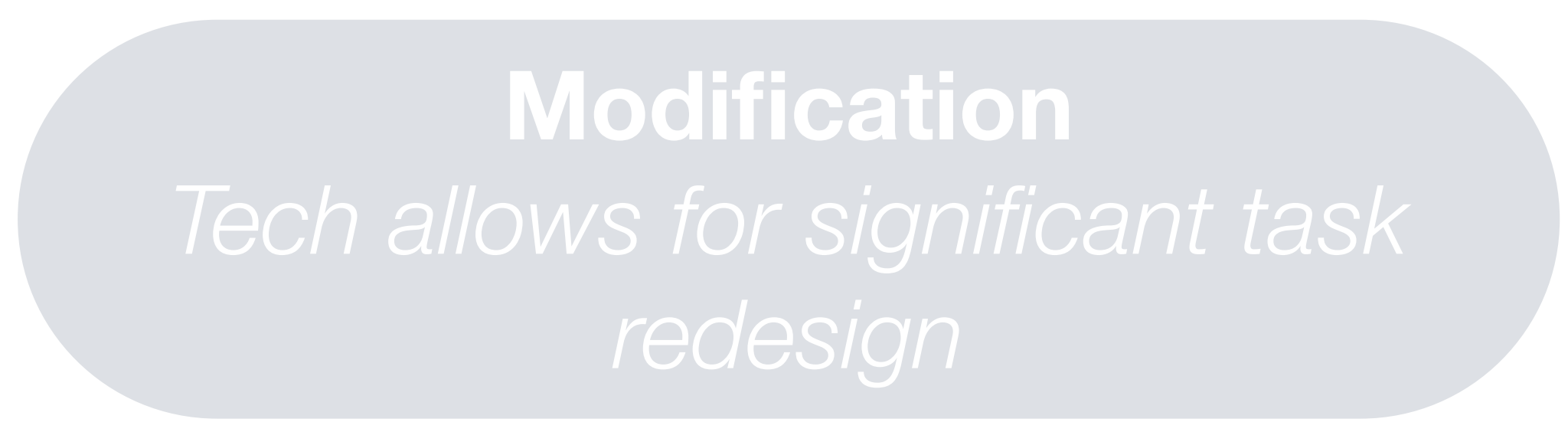

\section{Augmentation}

Tech acts as a direct tool substitute, with functional improvement
Digress.it

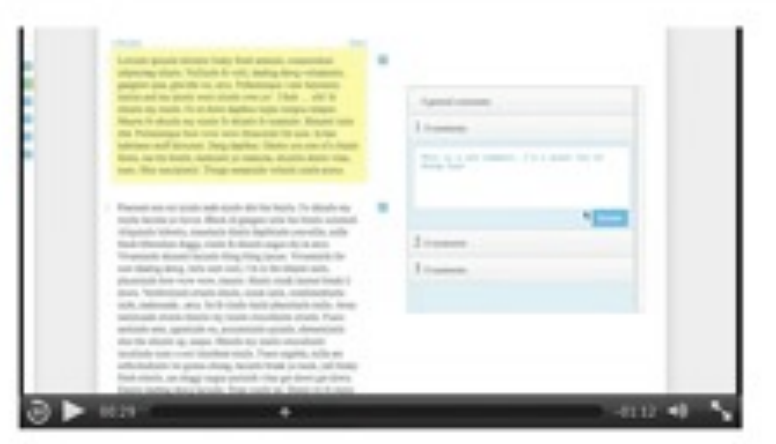

HOW ITS USED

TEACH

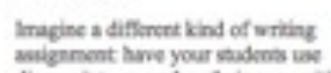

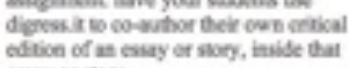

calay or ming.
About Eramples llatp Code Rogister Login

Encouraging Thoughtful Discussions

REGISTER

DOWNLOAD

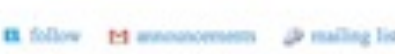

79

CRITIQUE

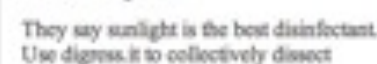

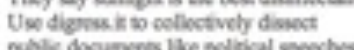

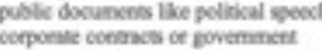

\section{Substitution}

Tech acts as a direct tool substitute, with no functional change 


\section{Redefinition}

\section{Tech allows for the creation of new tasks, previously inconceivable}

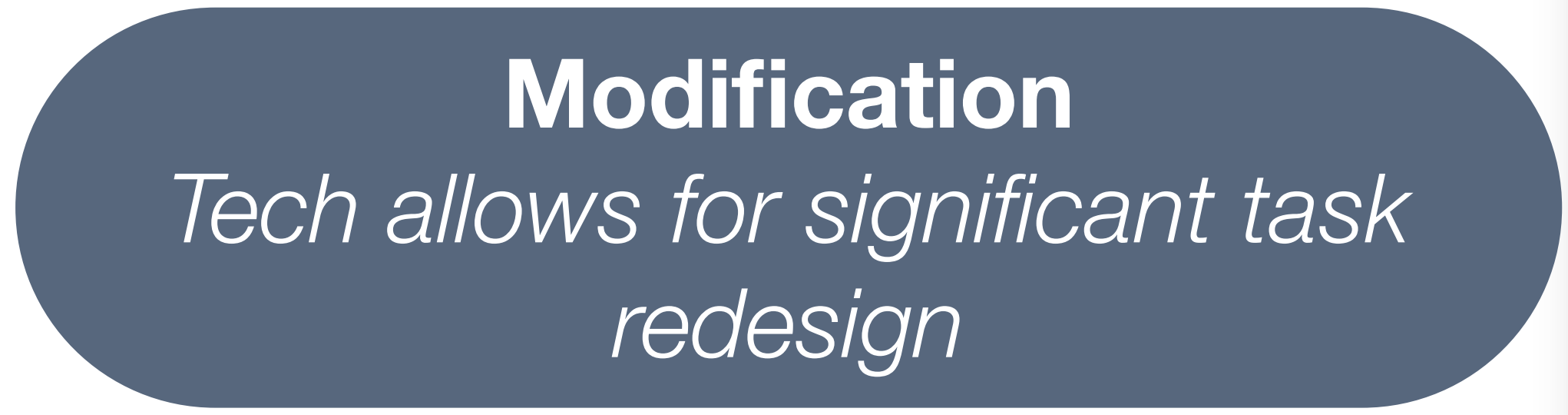

\section{Augmentation}

Tech acts as a direct tool substitute with functional improvement

\section{Substitution}

Tech acts as a direct tool substitute, with no functional change

\section{0 \\ Timeline}

brainpicker
Ooh! Audio of Alfred Hitchcock's Ghost
Stories for Young People youtu.be/z-
hlwwVDknM (cc: @openculture)




\section{Redefinition}

Tech allows for the creation of new tasks, previously inconceivable

\section{Modification}

Tech allows for significant task redesign

\section{ZTTE}

\section{Augmentation}

Tech acts as a direct tool substitute with functional improvement

\section{Substitution}

Tech acts as a direct tool substitute, with no functional change

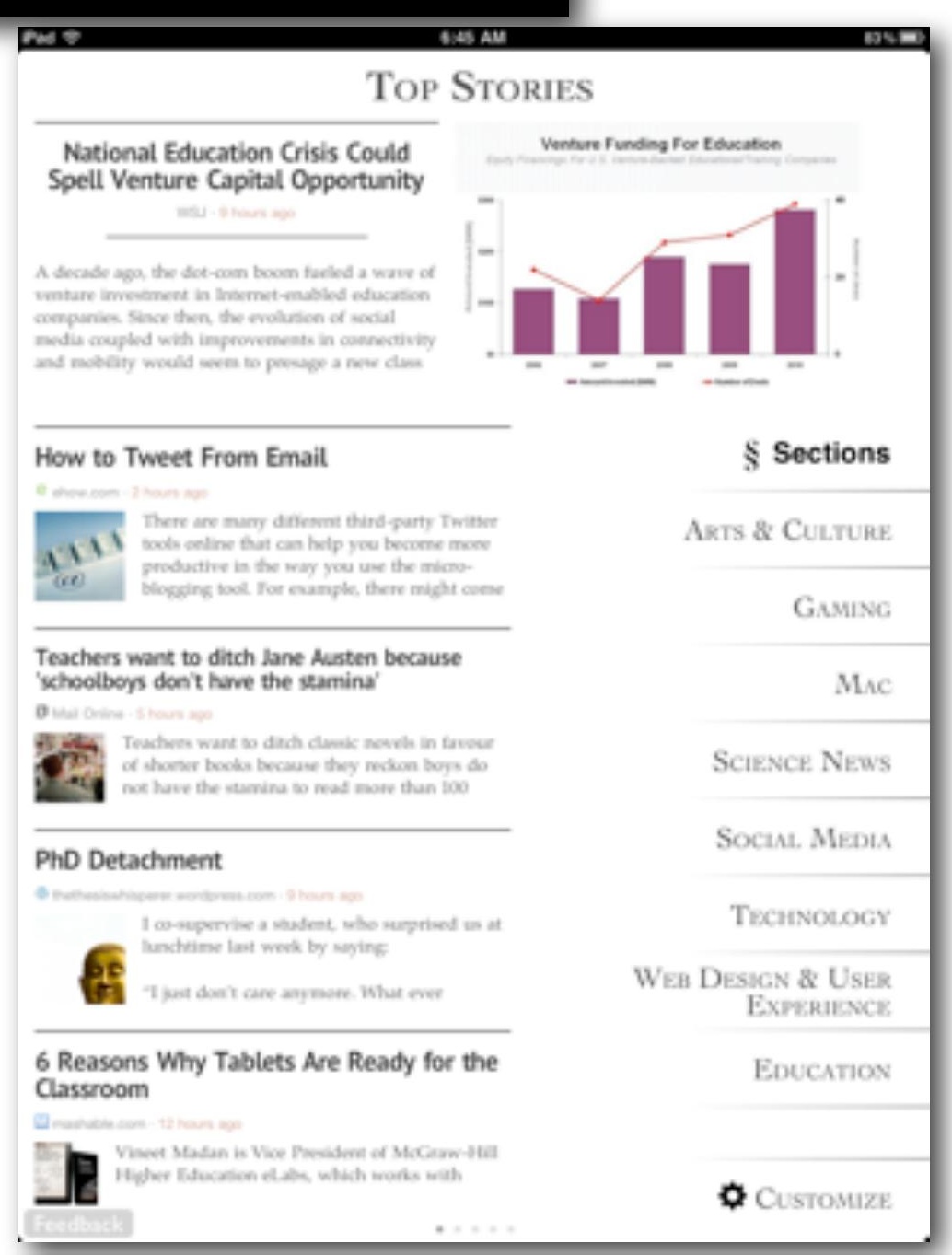


SAMR and Assessment 


\begin{tabular}{|c|c|c|c|}
\hline & Where the learner is going & Where the learner is right now & How to get there \\
\hline Teacher & $\begin{array}{l}1 \text { Clarifying learning } \\
\text { intentions and criteria for } \\
\text { success }\end{array}$ & $\begin{array}{l}2 \text { Engineering effective class- } \\
\text { room discussions and other } \\
\text { learning tasks that elicit } \\
\text { evidence of student } \\
\text { understanding }\end{array}$ & $\begin{array}{l}3 \text { Providing feedback that } \\
\text { moves learners forward }\end{array}$ \\
\hline Peer & $\begin{array}{l}\text { Understanding and sharing } \\
\text { learning intentions and } \\
\text { criteria for success }\end{array}$ & \multicolumn{2}{|c|}{$\begin{array}{l}4 \text { Activating students as instructional resources for one } \\
\text { another }\end{array}$} \\
\hline Learner & $\begin{array}{l}\text { Understanding learning } \\
\text { intentions and criteria for } \\
\text { success }\end{array}$ & \multicolumn{2}{|c|}{5 Activating students as the owners of their own learning } \\
\hline
\end{tabular}

Black, P. and Wiliam D. "Developing the theory of formative assessment." Educational Assessment, Evaluation and Accountability. 21:5-31 (2009) 


\section{Substitution: Sociology Online Discussion Rubric (Evans, 2010)}

\begin{tabular}{|c|c|c|c|}
\hline & 4 Points & 2 Point & 0 Points \\
\hline Content & $\begin{array}{l}\text { You show that you can apply or extend } \\
\text { the idea you are discussing. }\end{array}$ & $\begin{array}{l}\text { Some of your messages analyze, interpret, or apply the } \\
\text { material well, but some do not. This might either be } \\
\text { because the analysis was not done well, or because it } \\
\text { was not attempted (that is, was simply opinion or } \\
\text { hearsay). }\end{array}$ & $\begin{array}{l}\text { Your messages generally show } \\
\text { little evidence of analysis, } \\
\text { consisting instead of opinion, } \\
\text { feelings and impressions. }\end{array}$ \\
\hline Accuracy & $\begin{array}{l}\text { You accurately represent the concepts } \\
\text { discussed. }\end{array}$ & $\begin{array}{l}\text { You generally represent the concepts accurately, but you } \\
\text { do not do so in all cases. }\end{array}$ & $\begin{array}{l}\text { You have significant issues with } \\
\text { regard to accurately representing } \\
\text { the concepts. }\end{array}$ \\
\hline $\begin{array}{l}\text { Use of } \\
\text { material }\end{array}$ & $\begin{array}{l}\text { You use and cite sources, including the } \\
\text { text and articles and/or bring in an } \\
\text { outside source, all of which clearly add } \\
\text { significantly to the discussion. }\end{array}$ & $\begin{array}{l}\text { You clearly refer back to a definition, example or } \\
\text { concept from the reading or lecture. }\end{array}$ & $\begin{array}{l}\text { You do not bring in or refer to } \\
\text { any material from the text, } \\
\text { outside sources, or lectures. }\end{array}$ \\
\hline \multirow[t]{2}{*}{$\begin{array}{l}\text { Sociological } \\
\text { Analysis }\end{array}$} & $\begin{array}{l}\text { You focus on the sociological } \\
\text { implications of the issue at hand (e.g., } \\
\text { social meaning, the outcomes for society } \\
\text { or groups, the social function served). }\end{array}$ & $\begin{array}{l}\text { You touch on some sociological issues, but focus also } \\
\text { on individual ones. }\end{array}$ & $\begin{array}{l}\text { You focus primarily on individual } \\
\text { issues. }\end{array}$ \\
\hline & 2 Points & 1 Point & 0 Points \\
\hline Responses & $\begin{array}{l}\text { You extend or politely question the post } \\
\text { of another person in a way that advances } \\
\text { the discussion. }\end{array}$ & $\begin{array}{l}\text { You add new examples that continue the idea created by } \\
\text { another person. }\end{array}$ & $\begin{array}{l}\text { Your responses are primarily } \\
\text { agreement. }\end{array}$ \\
\hline Participation & $\begin{array}{l}\text { You write at least three or more } \\
\text { substantive comments (using the above } \\
\text { criteria) based on the discussion } \\
\text { assigned. }\end{array}$ & & $\begin{array}{l}\text { You write fewer than three } \\
\text { substantive comments. }\end{array}$ \\
\hline $\begin{array}{l}\text { Time of } \\
\text { Posting }\end{array}$ & $\begin{array}{l}\text { Your posts are spread widely during the } \\
\text { discussion. }\end{array}$ & You post at two significantly different times. & $\begin{array}{l}\text { Your posts are clustered within a } \\
\text { short period of time. }\end{array}$ \\
\hline Posts Read & $\begin{array}{l}\text { You have read at least } 75 \% \text { of the posts } \\
\text { in the discussion. }\end{array}$ & You read at least $50 \%$ of the posts in the discussion. & $\begin{array}{l}\text { You read less than } 50 \% \text { of the } \\
\text { posts in the discussion. }\end{array}$ \\
\hline Clarity & $\begin{array}{l}\text { You use standard grammar and spelling } \\
\text { and your meaning is clear. }\end{array}$ & $\begin{array}{l}\text { Your posts have some grammar or spelling mistakes or } \\
\text { your meaning is not entirely clear. }\end{array}$ & $\begin{array}{l}\text { Your posts have significant } \\
\text { grammar or spelling mistakes or } \\
\text { your meaning is not clear. }\end{array}$ \\
\hline
\end{tabular}




\section{Augmentation: A Branching Rubric for Writing (Hedrick, 2010)}

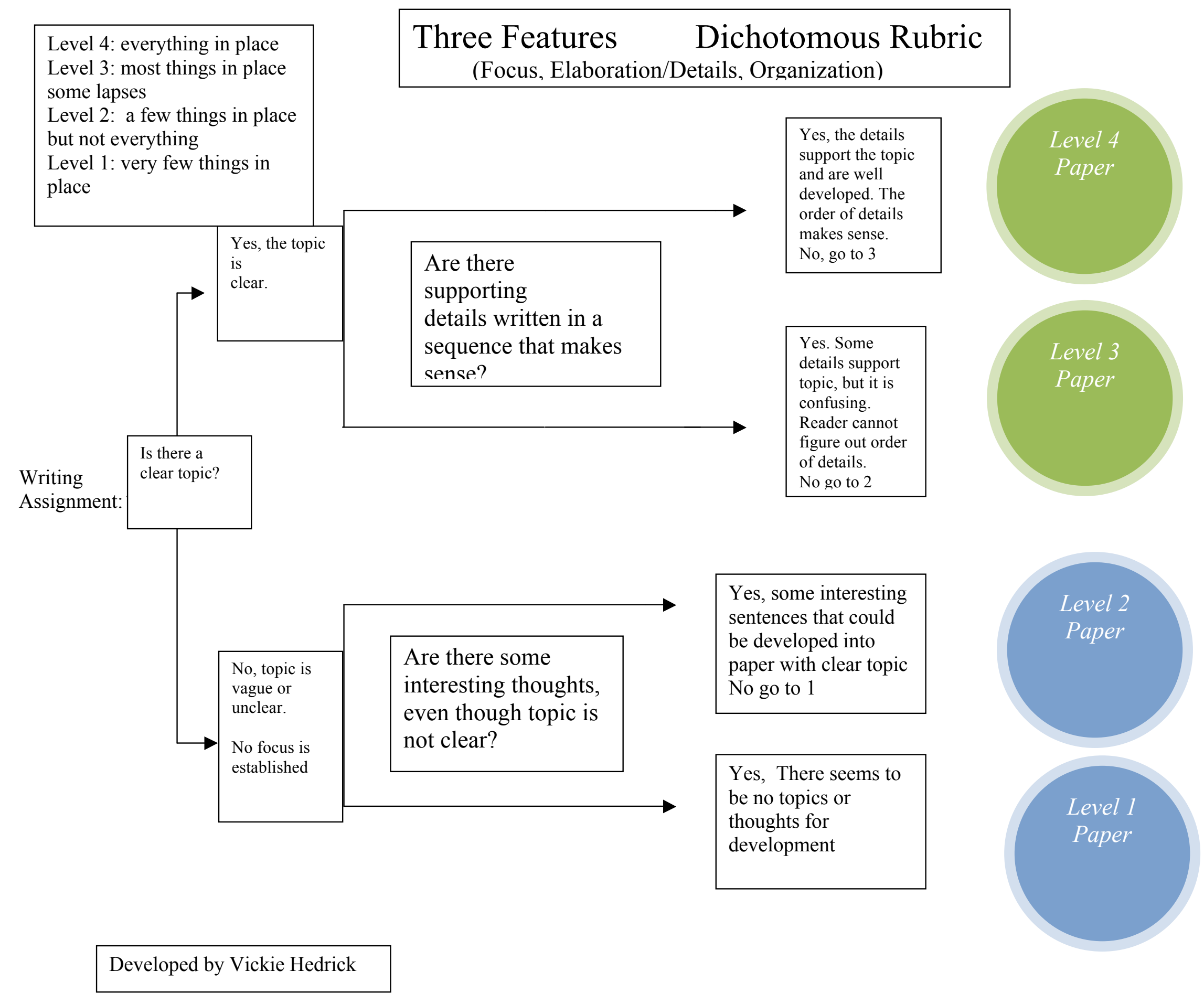

Hedrick, V. Continuous Improvement in the Language Arts Classroom. Quality Press (2010) 


\section{Modification: ConcepTests}

\section{(Mazur, 1997)}

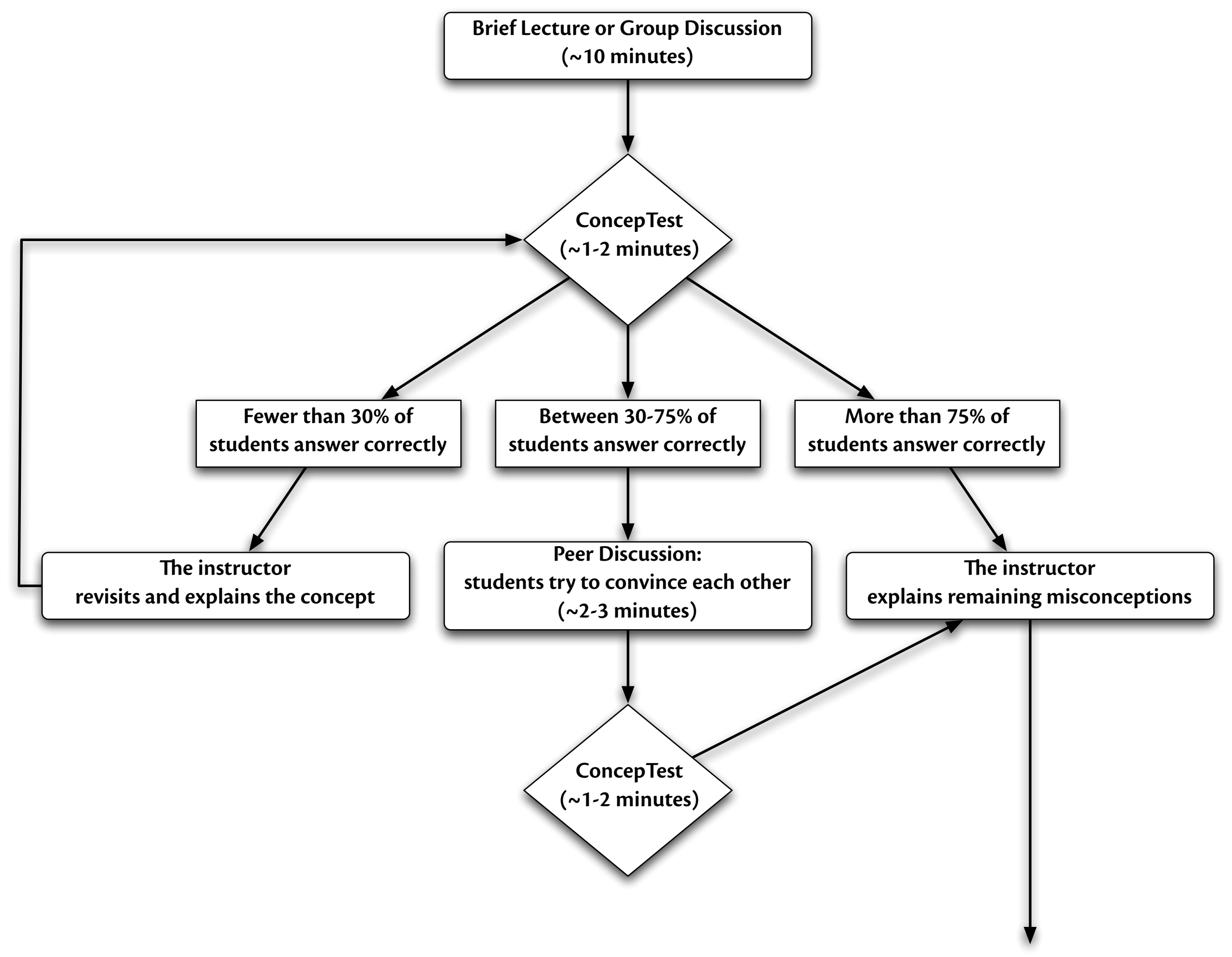

Mazur, E. Peer Instruction - A User's Manual. Prentice Hall (1997) 


\section{Redefinition: Designing for Wiki Learning (Beasley-Murray, 2008)}

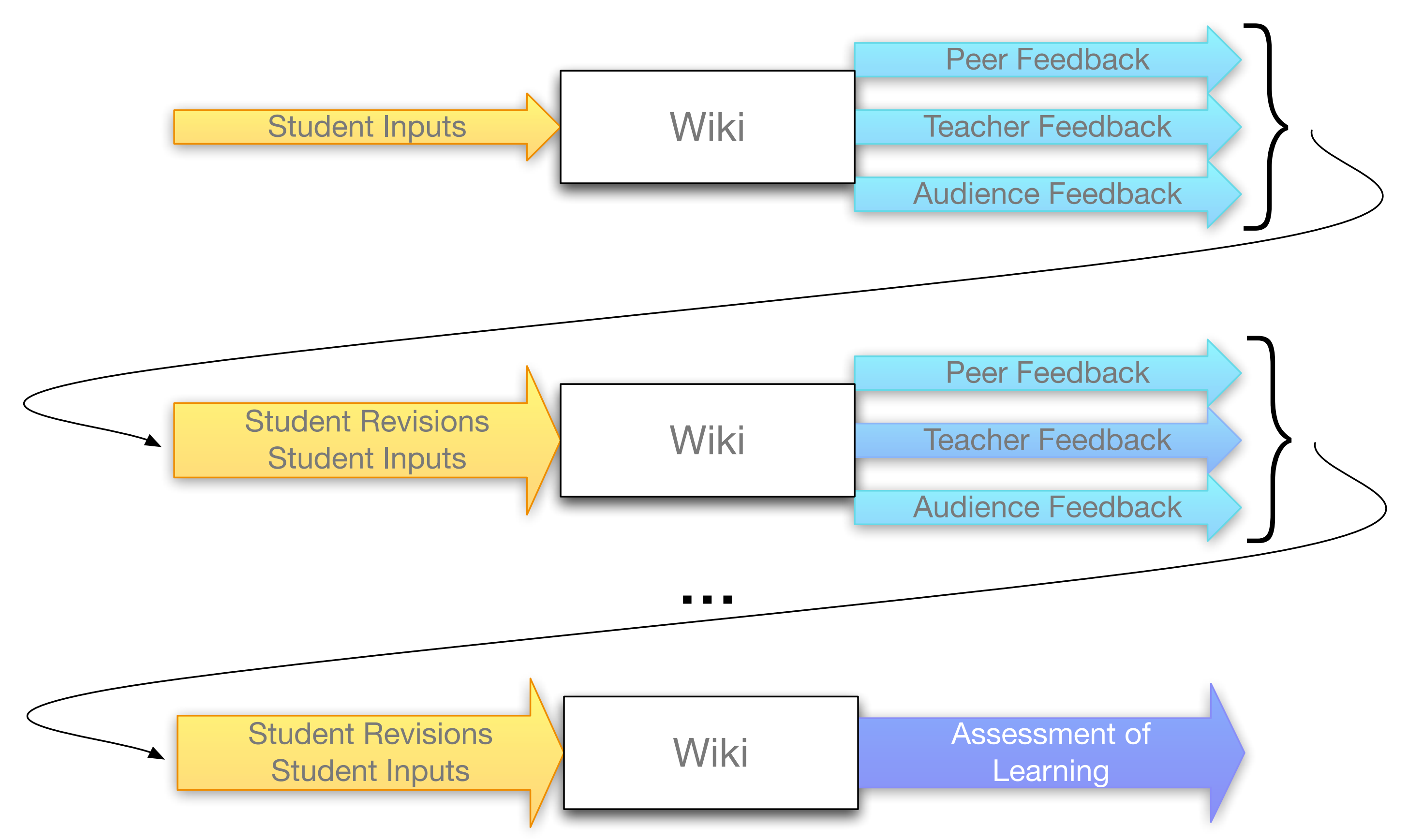

Wikipedia:WikiProject Murder Madness and Mayhem 
SAMR, the iPad, and AAC 


\section{Three Key Characteristics of Mobile Devices}

-Ubiquity

-Intimacy

-Embeddedness 


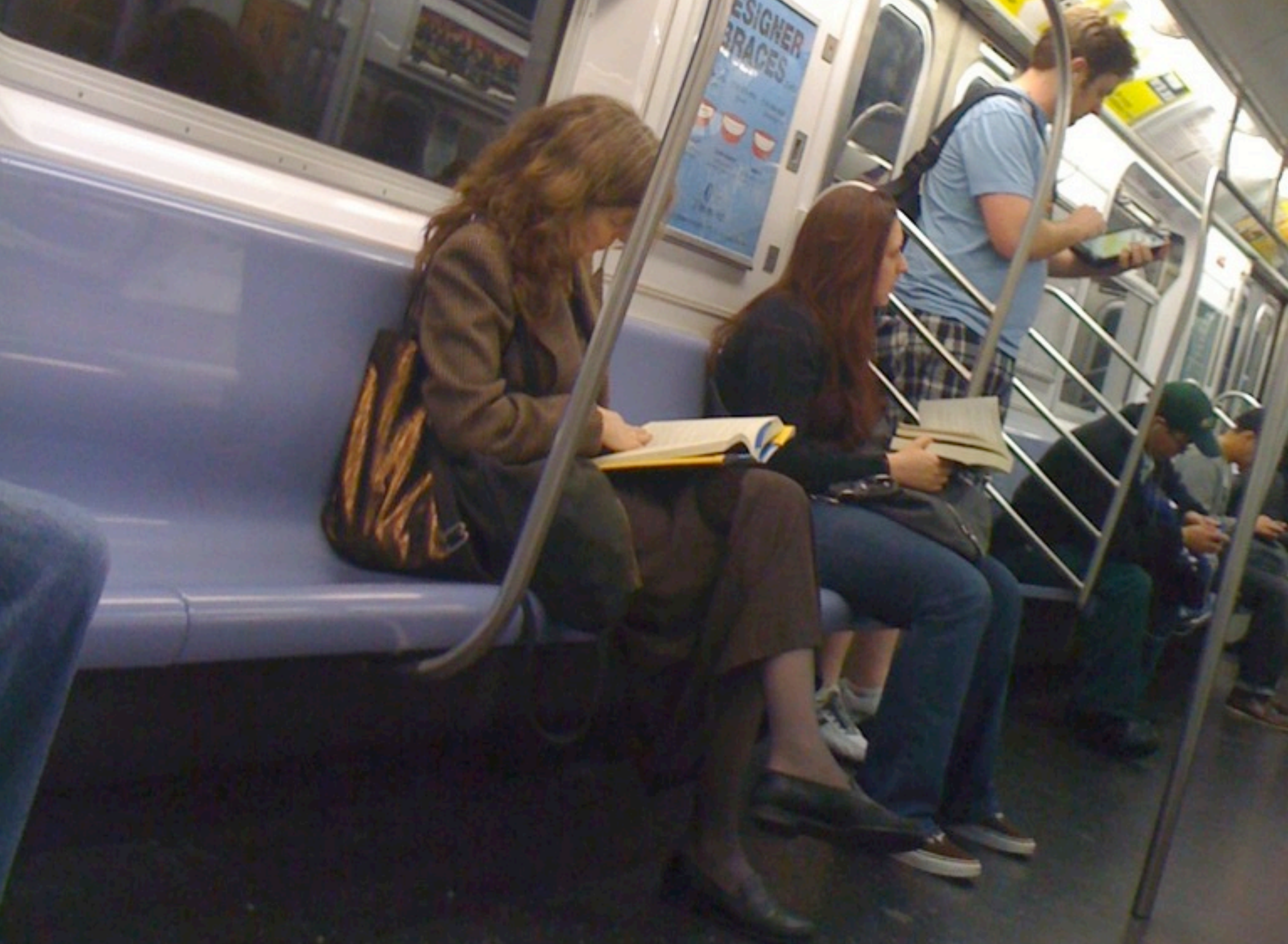




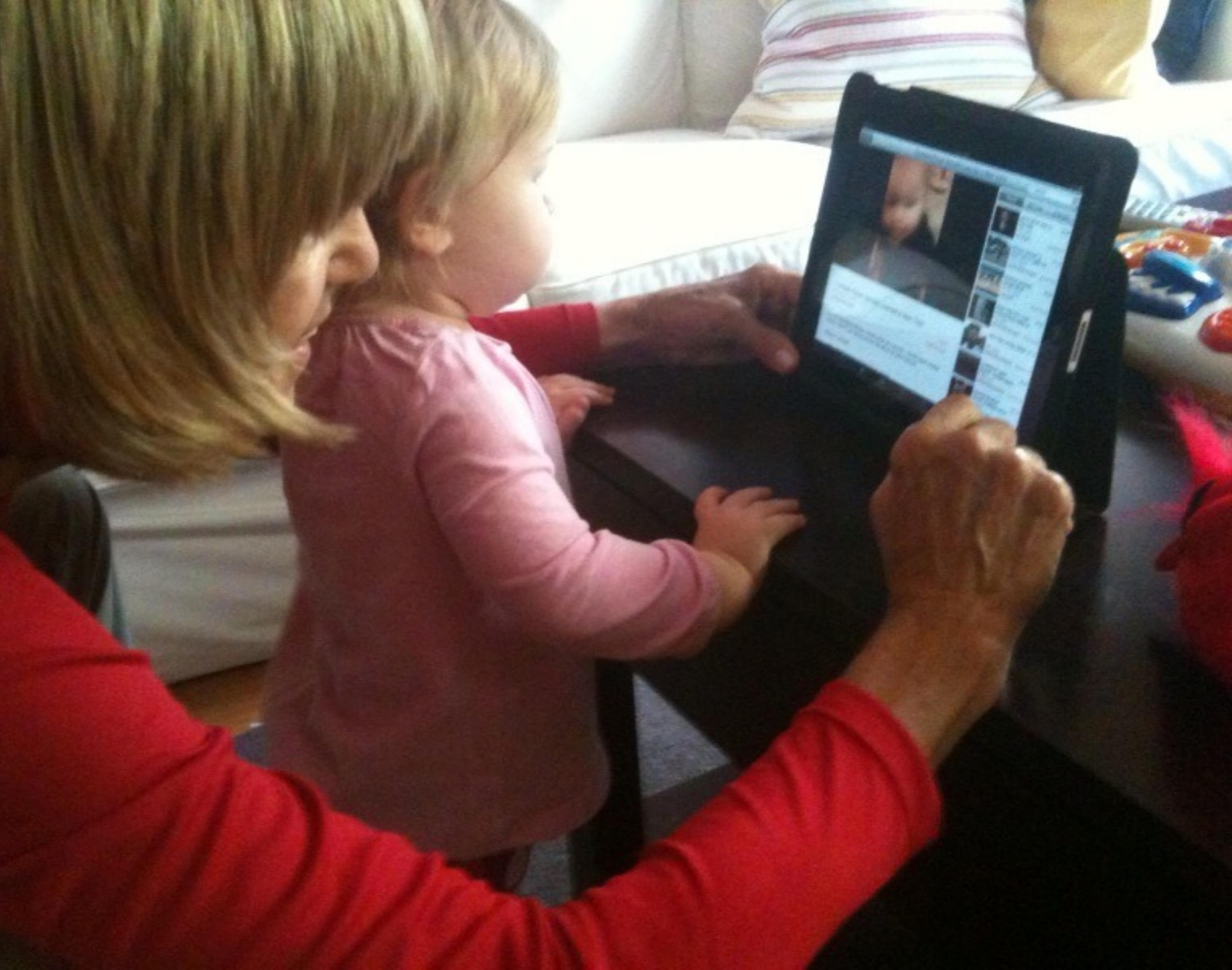





\section{Two Key Metaphors}

- The Lively Sketchbook

- The Curiosity Amplifier 


\section{A SAMR Ladder for AAC}

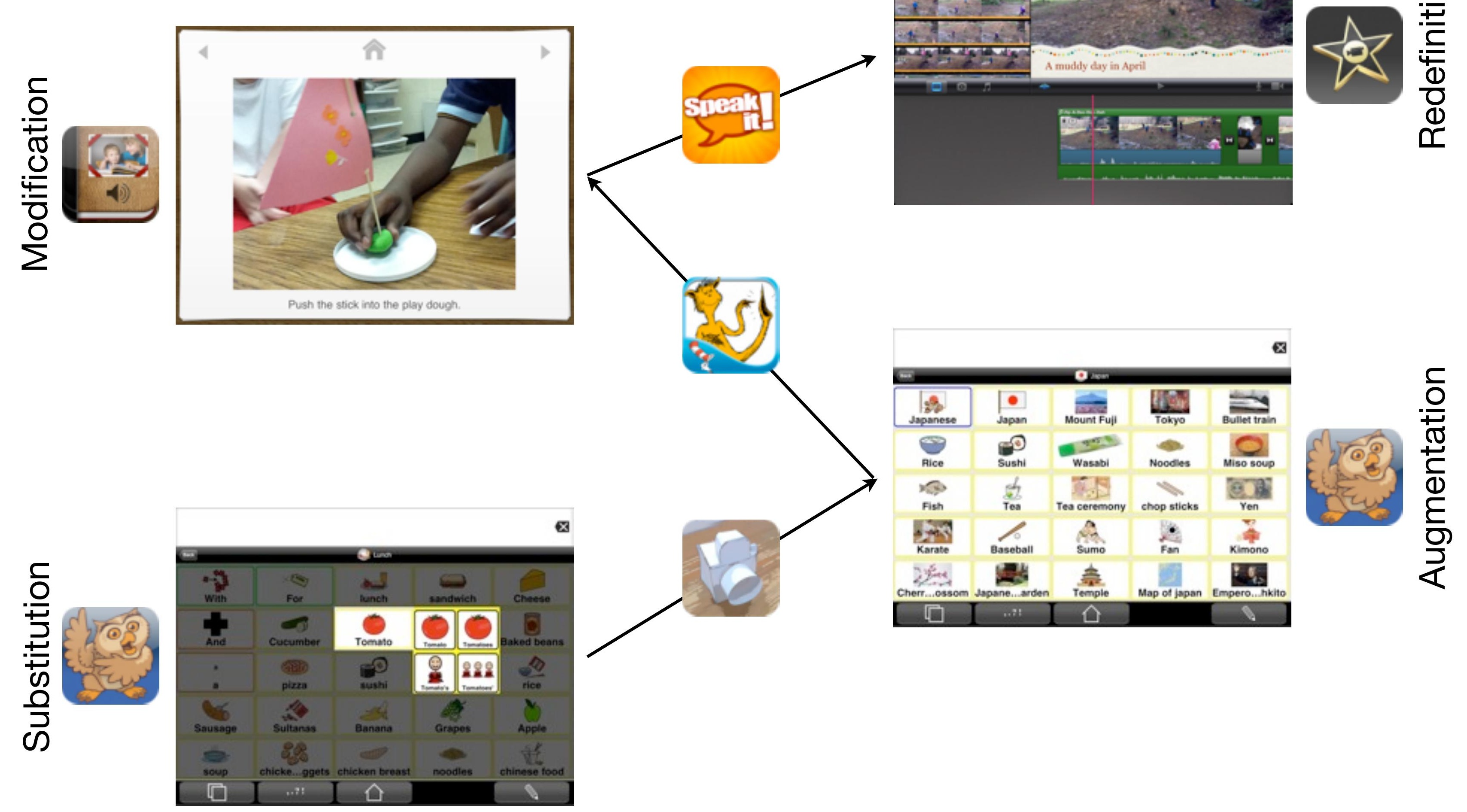




\section{Epilogue: The TPCK Model}




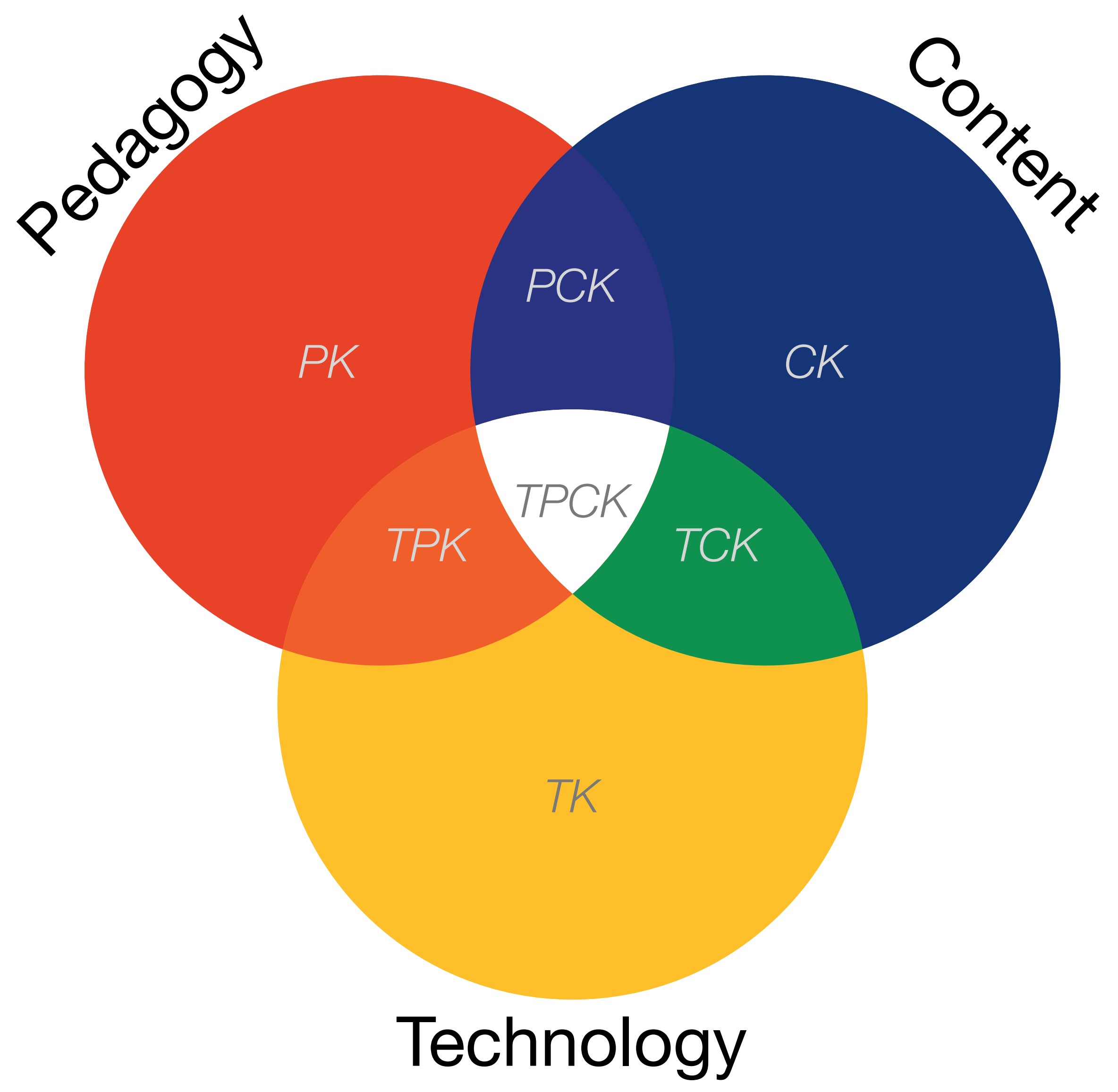




\section{Additional Resources}




\section{Resources - Part 1}

\section{Metaphors:}

- Vannevar Bush, “As We May Think”. The Atlantic Monthly. (July 1945) Online at: http://www.theatlantic.com/magazine/archive/1969/12/as-we-may-think/3881/

- Douglas C. Engelbart, A Research Center for Augmenting Human Intellect. (December 1968 live demo) Archived online at: http://sloan.stanford.edu/mousesite/1968Demo.html

- Alan Kay, "A Personal Computer for Children of All Ages". Proceedings of the ACM National Conference. Boston (August 1972) Online at: http://www.mprove.de/diplom/gui/Kay72a.pdf

- Seymour Papert, "On Making a Theorem for a Child". Proceedings of the ACM National Conference. Boston (August 1972) Online at:

http://portal.acm.org/citation.cfm?id=569942

\section{SAMR and TPCK:}

- Ruben R. Puentedura, Transformation, Technology, and Education. (2006) Online at: http://hippasus.com/resources/tte/

- Ruben R. Puentedura, As We May Teach: Educational Technology, From Theory Into Practice. (2009) Online at: http://tinyurl.com/aswemayteach

- TPCK - Technological Pedagogical Content Knowledge. (2008-2010) Online at: http://www.tpck.org/tpck/index.php?title=Main_Page

- AACTE (Eds.) The Handbook of Technological Pedagogical Content Knowledge for Educators. New York:Routledge, 2008. 


\section{Resources - Part 2}

Defining Mobile Devices/The Lively Sketchbook

- Ruben R. Puentedura, "Drawing On The Lively Sketchbook". Connect@NMC Talks. (2010) Online at: http://www.nmc.org/connect/2010/april/16

- Ruben R. Puentedura, "The Lively Sketchbook". (2010) Online at: http://www.hippasus.com/rrpweblog/archives/2010_01.html

\section{The Curiosity Amplifier}

- John Seely Brown. "A New Culture of Learning”. NMC Summer Conference, Closing Keynote. (2010) Online at:

http://www.nmc.org/2010-summer-conference/jsb-keynote-video 


\section{Photo Credits}

- iPad in Subway: Takashi M

- YouTube + iPad + Hanalei = Happiness: Wayan Vota

- Parcours-jeu multimedia : Les métiers du musée: Jean-Pierre Dalbéra 


\title{
Hippasus
}

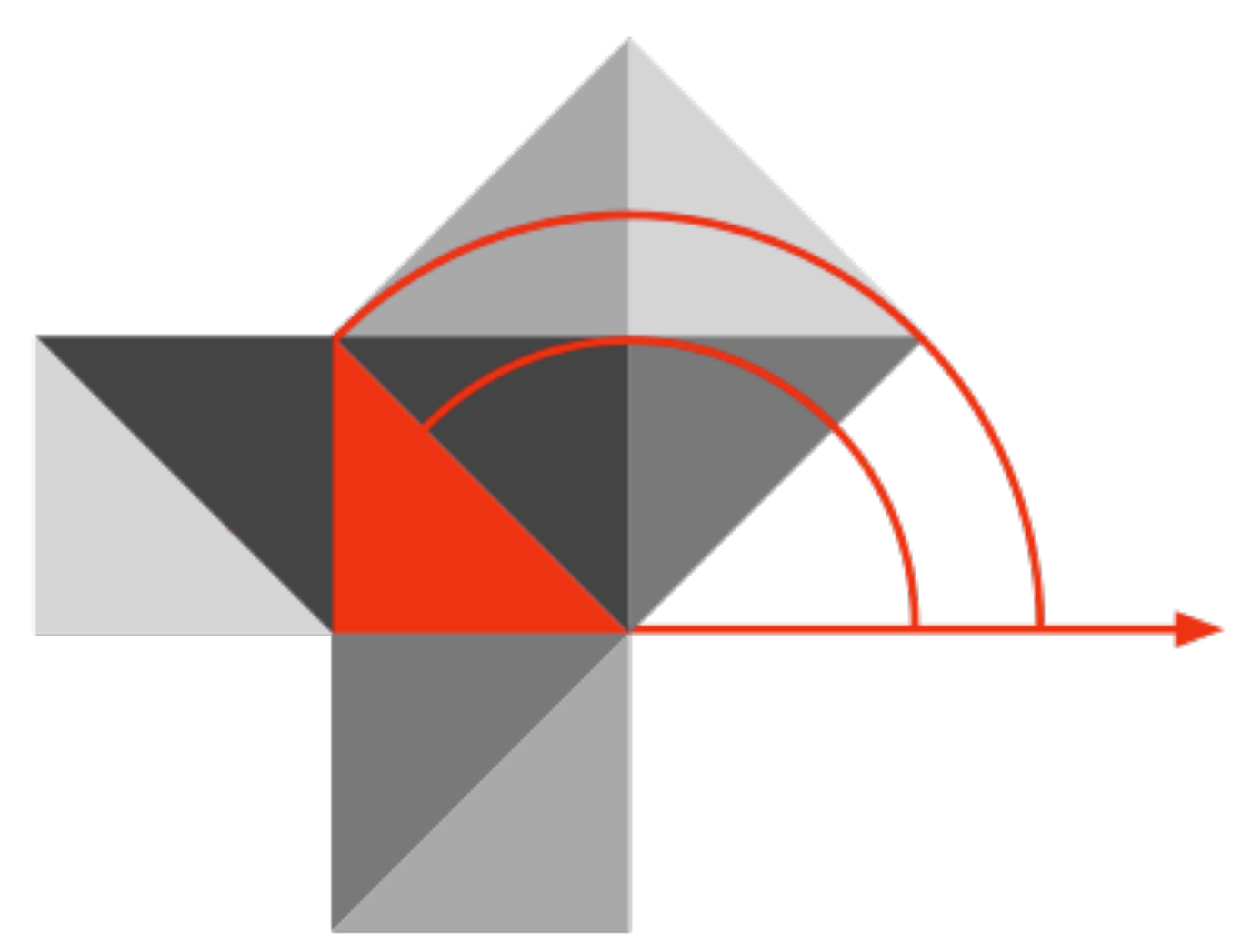

\section{Blog: http://hippasus.com/rrpweblog/ Email: rubenrp@hippasus.com}

\author{
Twitter: @rubenrp
}

This work is licensed under a Creative Commons Attribution-Noncommercial-Share Alike 3.0 License.

(2) 100 